Article

\title{
Adoption of Advanced Technologies in Palm Oil Milling Firms in Malaysia: The Role of Technology Attributes, and Environmental and Organizational Factors
}

\author{
Sima Parvand ${ }^{1, *(\mathbb{D})}$ and Rajah Rasiah ${ }^{2, * \mathbb{D}}$ \\ 1 Department of Development Studies, Faculty of Economics and Administration, University of Malaya, \\ Kuala Lumpur 50603, Malaysia \\ 2 Department of Economics, Faculty of Economics and Administration, University of Malaya, \\ Kuala Lumpur 50603, Malaysia \\ * Correspondence: sm.parvand@gmail.com (S.P.); rajah@um.edu.my (R.R.)
}

Citation: Parvand, S.; Rasiah, R. Adoption of Advanced Technologies in Palm Oil Milling Firms in Malaysia: The Role of Technology Attributes, and Environmental and Organizational Factors. Sustainability 2022, 14, 260. https://doi.org/ $10.3390 /$ su14010260

Academic Editor: Claus G. Sørensen

Received: 30 August 2021

Accepted: 9 December 2021

Published: 27 December 2021

Publisher's Note: MDPI stays neutral with regard to jurisdictional claims in published maps and institutional affiliations.

Copyright: (C) 2021 by the authors. Licensee MDPI, Basel, Switzerland. This article is an open access article distributed under the terms and conditions of the Creative Commons Attribution (CC BY) license (https:// creativecommons.org/licenses/by/ $4.0 /)$.

\begin{abstract}
Malaysian palm oil mills have lagged behind in the adoption of advanced milling technologies, both to support productivity growth as well as meet sustainable development goals. Using primary data from a simple random sample of 54 mills, this study sought to examine the factors explaining the adoption of advanced milling technologies. The results from the logit regressions deployed show that top management support and mill size act as key drivers of new technology adoption. Importantly, organizational factors were more critical in the adoption of advanced milling technologies than technological and environmental factors. However, financial support and resources, technical skills, complexity, cost, and government support produced negative coefficients among the non-adopters. The results should help mill owners, managers, and policymakers to remove the barriers facing the non-adopters, and to create effective strategies to stimulate the adoption of advanced milling technologies.
\end{abstract}

Keywords: advanced milling technology; adoption; T-O-E model; palm oil mill; Malaysia

\section{Introduction}

The Malaysian oil palm milling sector grew rapidly following government efforts to diversify agricultural exports since the 1970s. In 2019, the number of operating mills was 452 , with a production capacity of 112.91 million tonnes of fresh fruit bunches (FFB) per year. This sector significantly contributed to the revenue of the oil palm industry [1] with export revenue reaching RM38.03 billion (USD 9.3 billion) in 2019 [2].

Domestic demand for palm oil aimed at food consumption, industrial non-edible, and biodiesel uses have been forecasted to rise by over $200 \%$ to 1.4 million tonnes in 2035, with exports to rise by over 25 million tonnes in 2035 [3]. Given the exhaustion of arable land in Malaysia, it is critical that the focus by the government and firms shift towards the use of advanced technologies to meet the expected growth in demand over the period from 2021-2030. Furthermore, given the alarming levels of deforestation and its consequent impact on climate change and global warming, the government has been increasingly emphasizing the need for green oil palm cultivation, which has also been strongly influenced by pressure from developed country markets.

It is clear from past studies that technological change will have to play a major role in growth of the palm oil industry in Malaysia (see [4]). In the palm oil milling industry, technology is largely associated with the use of machinery and equipment for multi-purpose functions, problem-solving, and creating value [5-7].

Although the utilization of advanced milling technologies is widespread across the palm oil milling industry, there are still several firms that continue to rely on second and third-generation milling technologies. Adzmi Hassan et al. [8] provided evidence 
to show that only $58 \%$ of palm oil mills in Malaysia operated with moderate efficiency, and another $18 \%$ were efficient. Although palm oil mills (POMs) need to adopt advanced milling technologies to raise efficiency and productivity, the remaining firms have yet to do so owing to the challenges they face [9]. Existing accounts of explaining why so many POMs have not adopted advanced technologies have not gone beyond a lack of financial resources and awareness to address this problem [10]. Therefore, investigating the critical factors that drove the adoption of advanced milling technologies and the barriers that have discouraged others will be important to address the problem.

Consequently, this study focuses on the adoption of advanced milling technologies in palm oil milling processes due to the high efficiency of these technologies in reducing oil loss and its capacity to reduce palm oil mill effluents (POME), as well as to achieve zero-emission of methane gas [9-11]. These developments clearly show that the latest milling technologies emphasize sustainability issues.

Identifying the critical factors that stimulate the adoption of advanced milling technologies among POMs can assist planning by policymakers and mill managers [12-14]. While there are several studies that have addressed new technology adoption e.g., [15-17], few have focused on milling technologies. The few exceptions include Yahaya and Lau [9] and Adzmi Hassan et al. [8]. Moreover, the latter studies have not rigorously tested the variables believed to be the drivers of advanced milling technology adoption and their barriers, especially in SMEs and large milling firms. Hence, two questions are raised: does size influence the adoption of advanced technologies, and should this study investigate SMEs and large firms separately?

Therefore, this study seeks to fill the gap by testing several critical hypotheses on the drivers and barriers explaining the adoption and non-adoption of advanced milling technologies in Malaysia's POMs. Technology adoption by firms depends on the technology's characteristics and other factors related to inter-organizational and environmental features. It is for these reasons that we deploy the technology-organization-environment (TOE) framework [18] and the diffusion of innovation (DOI) [19] to investigate the adoption and non-adoption of advanced milling technologies by Malaysian POMs.

\section{Literature Review}

Unlike typical assessment of technology adoption, we focus the review specifically on the drivers of the adoption of advanced milling technology as this is a very processedbased industry that is quite different from other industries. The purpose is to obtain a focused review from the perspective of evolutionary theory, which stipulates that they are conditioned by the type of industry, timing, and location [20].

\subsection{Advanced Milling Technologies}

Developing palm oil processing technologies requires effectively addressing the main challenges that create difficulties for mill firms, which include minor improvement to oil extraction rate (OER) and checking the sharply increasing production costs. Spiraling costs of machinery and their maintenance, stagnant productivity, and ecological problems that attract bad publicity have combined to affect prices and demand. The solution would require the installation of environment-friendly, less labor-intensive, and more creative production organizations that use advanced milling technologies.

Advanced milling technologies embrace a diverse range of process technologies that have been known as the second and third generation of palm oil process technologies. Since most advanced milling technologies carry multiple functions and aimed at increasing productivity by improving product recovery, they support quick decision making. A number of these technologies have been developed and introduced in palm oil milling, such as in the sterilization process. For example, continuous sterilization with inclined and spherical sterilizers [21], tilting sterilizers, and vertical sterilizer [22], as well as the modification of steam distributors and sterilization cages have raised sterilization efficiency in milling firms. In addition, new oil extraction machinery in the shape of a double 
screw press has expanded the screw pressing capacity, thereby increasing milling firms' oil extraction rate. The entry of more efficient third-generation technology in the oil extraction process has enabled oil recovery by utilizing solvent extraction in milling firms.

The introduction of a two-phase decanter to remove the dilution of the hot water needed for clarification has considerably lowered the quantity of POME produced [23,24]. The POME output fell by around 50\% compared to conventional oil recovery utilizing vertical clarifiers [25]. To achieve this, the bigger firms have replaced biological treatment using water waste treatments with rapid anaerobic digester tanks that also produce biogas. The automatically assisted aerobic processes have with the support of tertiary treatment plants have also helped meet the legal discharge restrictions [25].

Although there has been a surge in advanced milling technologies across the palm oil industry, the adoption rate has been low. Bello and Abdul Raman [26] found that more than $85 \%$ of milling firms are based on anaerobic ponding systems, while the rest implement open digestion tanks. They also confirmed that although the second and third generations of POME treatment technologies could increase process performance to meet the zero discharge limits imposed by the Malaysia Department of Environment, most of them are yet to be adopted at large-scale. This gap calls for understanding as to why advanced milling technology remains rarely used in POM firms in Malaysia.

\subsection{PESTEL Analysis}

Sustainability performance of palm oil production in Malaysia calls for selecting appropriate strategies for addressing the identified POME and GHG emission from open digesting tanks in palm oil mills to tackle ecological problems to improve sustainability. Hence, sustainable adaptation planning should be all encompassing after considering the rapid technological changes, which might influence adaptation options [27].

To guide strategic decision-making, PESTEL analysis is one of the strategic frameworks used to assess the external environment of a company. The aim of the PESTEL analysis is to identify the key factors affecting the activities of the company or group of organizations. These key factors are Political, Economic, Social, Technological, Environmental, and Legal. The political factors looks at how government policy and actions intervene in the economy and other factors that can affect a business. The economic factors refers to the various aspects of the economy such as economic growth rates, interest rates, exchange rates, inflation unemployment rates and how their viewpoints on each area could impact a company. The social factors are related to the cultural and demographic trends of society. The technological factors address the innovation in the industry, such as R and D activity, automation, technological incentives, and rate of change in technology. The environmental factors are related to the ecological impacts on a company. The legal factors regards the industry regulation, licenses, intellectual property, law regarding environmental protection.

Although some studies employed the PESTEL analysis framework to evaluate the impact of key factors on adoption (e.g., [28]), the evidence shows that adaptation theory focuses less on other actors (such as firms, suppliers and policymakers) that may be important for the build-up and diffusion of systems [29]. Hence, this study seeks to develop a holistic conceptual model by the TOE framework.

\subsection{TOE Framework}

The extant literature on technology adoption indicates that the socio-economic characteristics and the technology acceptance model (TAM) specifically target technology acceptance for understanding users' adoption, which often underpins studies on palm oil processing e.g., [15-17,30-32] (Technological adoption requires learning and soft adaptation by human capital that uses it, including production reorganization. However, it does not require the development of profound physical adaptation of technologies, albeit the latter would surely enhance the technological capabilities of firms [33]). Due to the focus on POM's adoption, this study applied the most commonly adapted TOE framework [18] to investigate the critical adoption or non-adoption factors of advanced milling technologies by 
POMs in Malaysia. The TOE constructs have been applied in various technology adoption studies with a significant level of dependability and predictability of adoption e.g., [34-36]. The technological construct addresses the suitable technologies available inside the firms and the market pool. In contrast, the organizational context refers to the administrative aspects and resources, such as scope, size, hierarchy, and organizational structure. The external environmental context refers to environmental traits, such as consumers, competitors, and government regulations.

However, because of the TOE framework's limitations on providing specific characteristics of technological innovations in advanced milling technologies, this study absorbed elements of DOI theory by Rogers [19] to investigate the critical technological adoption factors of advanced milling technology. The TOE-DOI integrated model explains better technology adoption [37,38] and its competitive advantages [39], which provides higher level of reliability and validity. Although this integrated framework has been deployed at the organizational level to investigate the adoption of new technologies, it has yet to be applied for studying the adoption of advanced milling technology by Malaysian POMs.

The DOI theory postulates adoption as a function of innovation attributes that covers five technological characteristics [19], which comprise relative advantage, compatibility, complexity, observability, and trialability that may raise or reduce technology adoption $[35,36]$. This study adopted two technological constructs from the DOI theory, which covers the specific aspects of advanced milling technology and added the factor cost of technology innovations [34-40].

Hence, the conceptual framework developed for this study takes account of the compatibility, complexity, and cost in the technological construct; financial support and resources; top management support; managers' knowledge, technical skills, and size of the firm in the organizational construct; and environmental pressure and government support in the environment construct.

It is essential to investigate the critical factors mentioned to determine a milling firm's ability to adopt innovative technology, especially advanced milling technologies. The support of these critical factors under each construct for advanced milling technology adoption by POMs is discussed below.

Figure 1 presents the analytic framework that combines the TOE and DOI models to adopt advanced milling technologies by Malaysian POMs.

\subsubsection{Technology Attributes}

Among other reasons, palm oil production costs are high owing to the high cost of third generation technologies, which is predominantly in installation and maintenance. While third generation efficient milling technologies have already entered the market, there is limited evidence of how they will affect overall production costs. Technology adoption is strongly shaped by perceived compatibility, that is, the degree to which an innovation is perceived to be consistent with current values, past experiences, and needs of adopters, as well as complexity, which is perceived as the degree of difficulty associated with understanding and using an innovation [19] (p. 15). Consequently, several studies indicate that perceived compatibility [36,37], perceived complexity [36-41], and costs [35-42] are critical predictors of adoption.

For the effective adoption of new technology, the firm should consider the technologies in the market and in-house technologies in use. From the adopters' viewpoint, compatible technologies would save money, time and meet government regulations, and consequently would require making justifiable changes and modifications to existing processes, instead of deconstructing and substituting them with incompatible technologies [43]. Parthasarathy et al. [44] found that the adopted aerobic pond system for POME treatment by Malaysian POMs was not aligned with discharge regulations due to inefficient operational design. Said et al. [45] reported that the major problem when using the membrane bioreactor during ultrafiltration of POME is generally caused by pore blocking at the membrane surface, which simultaneously affects the capital cost and maintenance. 


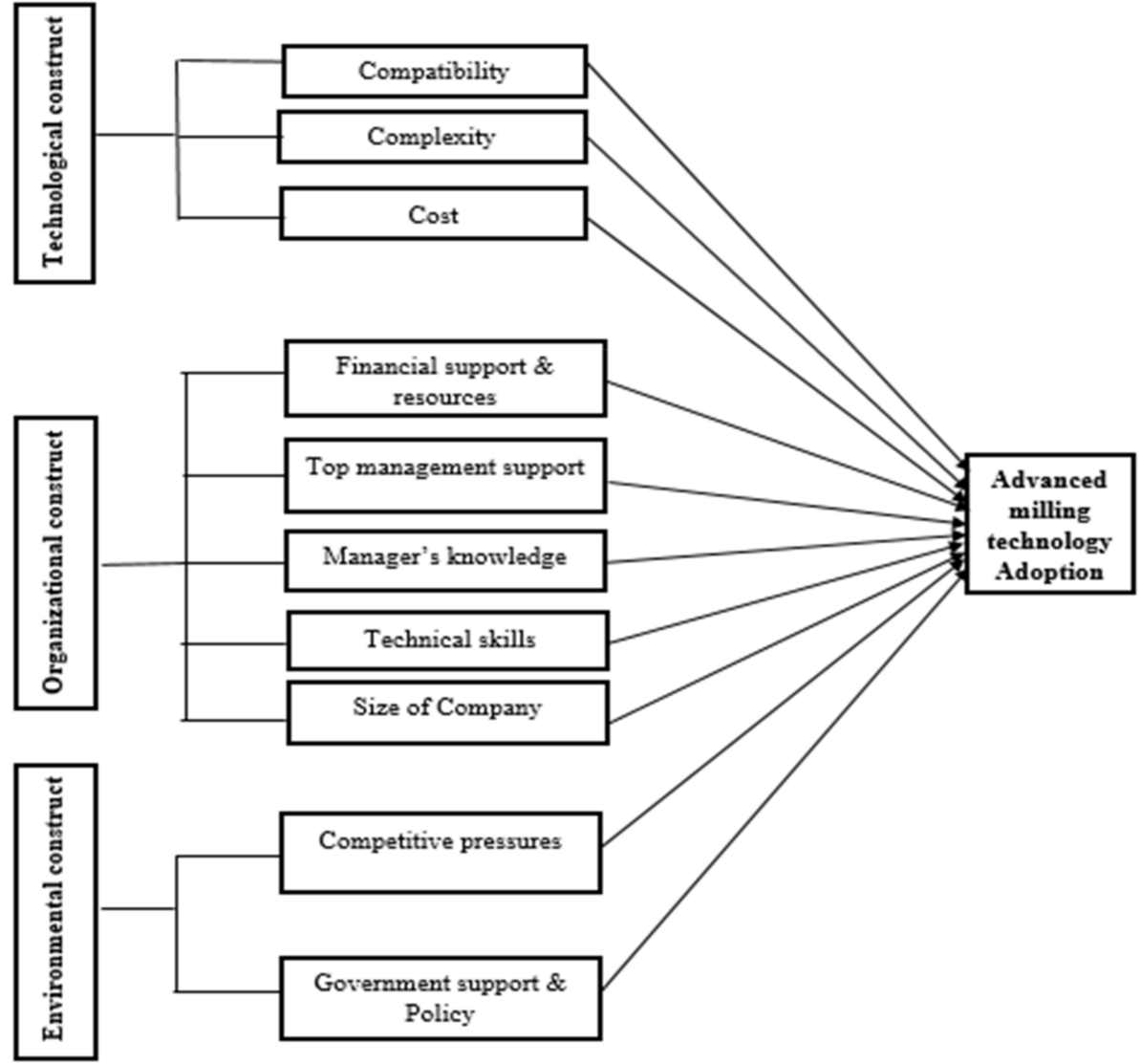

Figure 1. Analytic Framework.

Similarly, milling firms that adopted multiple screw presses for oil extraction using new technology have experienced challenges to control accurately the rate of water extra to the press liquor to improve the separation of oil/sludge through clarification [46,47]. Indeed, if POMs recognize that the efficient adoption of advanced milling technologies offers more compatibility and less complexity, they would more likely invest in these technologies.

There is also evidence that the cost and maintenance of new technologies have discouraged the adoption of advanced technologies in most parts of Asia and Africa, such as Nigeria, Egypt, Jordan, Syria, and Turkey [48]. Moreover, Yahaya and Lau [9] argue that several POMs in Malaysia have been reluctant to adopt advanced POME treatment technology due to the high initial investment cost. Many simply believe that reaching a final effluent discharge of biological oxygen demand (BOD) of less than 20 PPM by adopting Waterwaste treatment technology is too costly [49].

In addition, Baluch, Abdullah and Mohtar [50] note that most POMs outsource maintenance for new-generation decanters and turbines. Barrantes [51] argued that the adoption of technology that separates kernels from shells depends on the availability of the right technology, costs, and maintenance of equipment, and availability of machinery and materials (see also [52]). The following three critical hypotheses are proposed:

Hypothesis 1. Compatibility is a critical influence on milling firms adopting advanced milling technology.

Hypothesis 2. Complexity is a critical influence on milling firms adopting advanced milling technology.

Hypothesis 3. Cost is a critical influence on milling firms adopting advanced milling technology. 


\subsubsection{Organizational Constructs}

The organizational construct addresses the readiness for the utilization of internal resources [53]. Past works recognize that organizational structure plays an important role on innovation e.g., [54,55]. Yet, for a variety of reasons, adoption of critical technology by firms can be low [56] (Ukobitz [56] discussed the state in 3 dimensional printing). For effective adoption of new technologies, a decentralized and well-coordinated organizational structure with employees' responsibilities and creative communication is clearly defined, and centralized coordinated decision-making for implementing new technologies is vital [57,58]. Firms' owners and top managers as decision-makers of technology adoption should be knowledgeable enough to understand their firm, innovative technologies, and customer needs [59].

Organizational resources, and skilled and qualified human personnel are essential for developing and utilizing technology within firms [60], especially in firms that have adopted a complex technology. The lack of appropriate abilities and skills that can limit workers' productivity would in turn restrict the use of a given technology and could result in organizations facing challenges in applying new technologies [61].

Although innovation technologies are important to increase efficiency in organizations, their use is often faced by employees' resistance, mainly due to lack of communication about the strategic advantages of new technologies by the top managers [62]. Therefore, the role of top management support is fundamental to promote new technologies by introducing them within the firm's overall strategy and supporting innovations that run into the firm's main goal [57-63].

In addition to organizational resources regarding individuals, other features, such as information, equipment, and technology, financial support and resources are critical factors in stimulating innovation, adopting, and applying new processes and products in organizations. Due to the implementation of innovative technologies requiring capital investments, financial resources are vital for obtaining and supporting individuals to implement new technology, and related infrastructure for supporting innovation $[64,65]$.

Lastly, firm size is a significant factor in stimulating adoption of technological innovations $[66,67]$. Large firms have been the first innovation adopters to achieve more economic value and competitive advantage [68,69]. Hence, the critical factors identified for assessing adoption of advanced milling technologies include financial support and resources, top management support, managers' knowledge, technical skills, and firm size under the rubric of organizational dimension.

Financial support and resources are essential to support the adoption of several environmental practices for the successful adoption of technology-based plans [70-72] Firms' capacity bear installation costs significantly influence adoption decisions [73-76]. Hence, only firms with access to enough finance would be more able to adopt advanced technologies [74]. In palm oil milling technologies, firms have to bear lumpy investments to install third generation process technologies targeted at raising efficiency and productivity, and to reduce environmental pollution.

Management support has been recognized as a significant facilitator for firms in adopting technology $[77,78]$. Senior managers could positively affect the adoption of new technology by clarifying a vision and reinforcing the values of their organizations [35]. In general, passionate and innovative top managers welcome innovative technologies and are often ready take risks. Top management plays an essential role in gaining resources and in implementing plans [79]. In a firm where senior managers have a positive attitude to change, an organizational environment supportive of innovation is created. Thus, senior managers must provide their highest level of support and commitment to effect change [66-80], especially in the implementation stage, including in coordination and dispute resolutions [81].

Given that advanced milling technologies (which include a strong emphasis on strengthening sustainability), are incredibly diverse compared to conventional technologies in terms of innovation intensity and complexity, as well as their effective utilization, POMs 
need to support sustained efforts in technical skills and training to ensure that the adopted technologies meet their expected operational needs. Such efforts need enormous support from top management.

Furthermore, the knowledge and experience of individuals are an important determining factor for the choice of the channel [77]. Managers' knowledge and creativity play an important role in the adoption of technology; the higher these qualities are, the more likely a firm will adopt new technology [82-84]. Madaki and Seng's [85] study showed that the majority of POM operators (86\%) claimed to know the new POME treatment technologies, while $2 \%$ were involved in the $\mathrm{R}$ and $\mathrm{D}$ of new technology in collaboration with research institutes and universities in and outside Malaysia. Meanwhile, Nordin et al. [49] found that a few POMs have adopted patented zero-waste technology offered by MPOB due to the lack of knowledge of economic benefits of this technology.

Although advanced milling technologies have the potential to raise strongly milling efficiency, these technologies come with unique challenges, which include adaptation to meet local conditions. Hence, mill managers should be aware of these problems to undertake the changes required. For instance, although membrane filtration technology is a third generation oil recovery technology, it still needs further development to perfect materials use and cleaning techniques to overcome fouling problems [25].

Technological changes call for more skills and competencies for firms to compete. However, past works show that the lack of technical skills is a significant factor that has delayed the adoption of new technologies by POM firms [86]. Baluch, Abdullah, and Mohtar [50] and Baluch [87] went further to argue that the lack of in-house expert employees is one of the barriers that has restricted technological upgrading. Consequently, organizations must invest in cutting-edge technologies to compete effectively, which will invariably require the acquisition of new technical skills [88].

Typically, the financial reach of large firms has offered them the capacity to invest in risky and uncertain innovation activities [89-95]. First, considering the high risks and costs included in the early adoption of new technology, large firms are better endowed than small firms to allocate capital for adoption of new technologies. Second, in markets distorted by information asymmetries, large firms also have easier access to financial resources required for buying and installing new technology. Third, large firms typically have the human capital and requisite skills and other resources to introduce and implement new technology. Finally, large firms enjoy economies of scale to easily amortize investment in new technologies.

Meanwhile, Zhu and Kraemer [96] argued larger firms do not only have more financial resources for adopting new innovations, but also have the capacity to make adoption decisions more quickly than smaller firms. Such an argument has been contested though, by those who find specialization on the basis of economies of scope allows small lean firms to be more flexible to adopt new technologies [97]. Nevertheless, the scale-based nature of milling firms shows empirical support for scale see [37,98-101]. Consequently, we hypothesize that:

Hypothesis 4. Financial support and resources have a significant influence on the adoption of advanced milling technology.

Hypothesis 5. Top management support has a significant influence on the adoption of advanced milling technology.

Hypothesis 6. Managers' knowledge of new technologies has a significant influence on the adoption of advanced milling technology.

Hypothesis 7. Human capital endowed with technical skills has a significant influence on the adoption of advanced milling technology.

Hypothesis 8. Firm size has a significant influence on the adoption of advanced milling technology. 


\subsubsection{Environmental Constructs}

The environment has increasingly become a critical variable in the conduct and performance of firms [102]. (Maqueira-Marin et al [102] discussed environmental determinants of firms' adoption of cloud computing). Hence, firms consider a comprehensive management framework that embraces consumers, competitors, government regulations/supports, and technology vendors when making decisions on technology choice and adoption. In the context of advanced milling technology, hence, pressures arising from environmental stakeholders and related government support have become important determinants of the choice of technology in firms. The structure of the industry and the number of POMs using advanced milling technologies can affect adoption by other firms as these firms may not wish to fall behind in the competition ladder [103]. Therefore, environmental pressure is one of the influences firms take into account when adopting advanced technologies [104], though a negative relationship between environmental pressure and new technology adoption was found by others e.g., [37,105-107]. Such a finding could be a consequence of the difficulty POMs face trying to keep Crude Palm oil (CPO) production costs low as they often face considerable market uncertainty and volatile prices, and competition from substitutes, such as soyabean oil. Hambali [108] found this experience in Turkey. Hence, although advanced milling technology raises $\mathrm{CPO}$ production yields, the lumpy investments required to install them may discourage new buyers.

As a means to underwrite uncertainties and risks, the Malaysian government implemented various incentives for encouraging POMs to upgrade their technologies, including to install third generation advanced milling technologies. The Malaysian government made significant forays into such support when it launched the Second Industrial Master Plan in 1996 and the Third Industrial Master Plan in 2006 [109]. Additionally, to produce POME that conforms to the regulatory discharge limits, more efforts are being promoted by the government to develop additional treatment methods [110].

However, several Malaysian POMs consider that existing policies and incentives on biomass and biogas are not sufficiently incisive to convince them to pursue advanced POME treatment technology projects [85]. Consequently, Abas et al. [111] argue that the government should develop a comprehensive and transparent policy to support the biomass sector, which includes providing a subsidy to oil palm biomass projects among POMs in Malaysia. The extant literature on this issue revealed a lack of adequate government policies and incentives to support agricultural mechanization and industry for technologies e.g., $[15,33,86,112-114]$. The lack of government support seems to hamper the adoption of advanced milling technology in POMs in Malaysia. Therefore, we hypothesize that:

Hypothesis 9. Environmental pressure has a significant influence on the adoption of advanced milling technology.

Hypothesis 10. Supportive government policy has a significant influence on the adoption of advanced milling.

\section{Methodology and Data}

A hypothetical-deductive model was used to carry out this study, which allows us to carry out quantitative research, including the statistical evaluation of the occurring phenomena illustrated in Figure 1. In quantitative research based on the hypotheticaldeductive model, we familiarized with and analyzed the theoretical foundations that were carried out, built based on a review of the extensive literature and after conducting its critical analysis. This part was performed to define the research's analytical framework by exactly defining the existing and utilized terms (see [115]).

Furthermore, this study uses a correlational design, which is classified under nonexperimental quantitative approaches. Correlational design allows the description, assessment, and measurement of statistical relations between two or more variables [116]. To assess the research model and hypotheses, we designed a survey questionnaire by adapting items from prior studies on adoption of technology, which were measured using 
a five-point Likert scale, defined from strongly disagree to strongly agree, and a binary scale $(0,1)$ for new milling technology adoption.

The population of this study includes all POMs operating in Malaysia. Since advanced milling technology adoption is the concern of this study, the target respondents should possess the decision-making power to adopt new technologies and have sufficient knowledge about critical factors of new technology adoption that their mills face for adopting them. Thus, the targeted respondents were drawn from among the top management, including senior managers, general managers, managers or individuals in charge of $\mathrm{R}$ and $\mathrm{D}$ department, operational managers, and assistant mill managers, and the unit of analysis was one manager per mill.

The study used the standard sample size determination formula for a finite population $[117,118]$ from a simple random sampling method, which yielded 95 from a population of 450 palm oil mills. A structured mail questionnaire was formulated to collect data from the sampled mills. We also conducted a face to face interview with some respondents who agreed to participate but reported not receiving the mail questionnaire. We were able to use only 54 responses with a response rate of $56.8 \%$ (54/95).

To identify the threat of bias associated with survey research, we applied the standard approach to testing for non-response bias using the linear extrapolation method based on the assumption suggested by Lahaut et al. [119] and Armstrong and Overton [120], which compared subjects between the early and late responses. Hence, we identified early and late respondents based on the recorded response time to evaluate non-response bias. From a total 54 of reactions, the first 19 were considered early respondents as their responses were recorded in a short time. In contrast, the last 35 were deemed to be late respondents because of the forces applied to obtain them through reminder E-mails or phone calls. In the same vein, we employed a Pearson chi-squared test to find the presence of any differences between early and late respondents by comparing them to the demographical information collected in the survey. The findings indicated no difference between early and late respondents $(p>0.05)$ regarding the size, age, and type of ownership of the POMs.

In addition, we used a non-parametric method that covered the ordered nature of Likert scales as they possess distinct characteristics, such as continuous values and restricted range [121]. Consequently, the Mann-Whitney $U$ test was applied to the rest of the items to determine whether early respondents' answers differ significantly from late respondents. The findings indicated none of the items were significant; we concluded that no dissimilarities between early and late respondents were diagnosed. Thus, non-response bias is unlikely to impact the sample.

The study deployed SPSS 22 to conduct data analysis using the logit regression model as the data was not normally distributed. It derived $\mathrm{n}$ predictor variables that occur for the two particular responses, i.e., $Y=1$ adoption of advanced milling technology; $Y=0$ non-adoption of advanced milling technology. Ten independent variables were used in the regression. Based on Adéoti et al. [122], the logit model is defined by the latent variable $Y i$ as follows:

$$
E(Y i)=P(Y i)=\frac{e^{\alpha+\beta x i}}{1+e^{\alpha+\beta x i}}
$$

If the mill did not adopt new technology, the probability shift is denoted by:

$$
E(\text { no }- \text { adoption })=P(Y i)=\frac{1}{1+e^{\alpha+\beta x i}}
$$

where $P(Y i)$ is the probability of a mill $i$ to adopt the new technology; $Y i=1$ if the new technology is adopted and $Y i=0$ if the new technology is not adopted.

Founded mathematically on a linear model of the natural logarithm of the odds in favor of $Y i=1$, subsequently, the logarithmic. odds of adoption and non-adoption of advanced milling technology can be written as: 


$$
\operatorname{Ln} \frac{P}{1-P}=\beta_{0}+\beta 1 X_{i 1}+\beta 2 X_{i 2}+\beta 3 X_{i 3}+\beta 4 X_{i 4}+\beta 5 X_{i 5}+\beta 6 X_{i 6}+\beta 7 X_{i 7}+\beta 8 X_{i 8}+\beta 9 X_{i 9}+\beta 10 X_{i 10}
$$

Several tests were conducted to determine the efficacy of the logit regression model of the TOE factors. The key parameters were significant to allow interpretation of the results. Firstly, the likelihood ratio conducted to test the improvement of the new model was significant at the 5\% level. Secondly, the Pearson chi-square test of goodness of fit of the model, i.e., the linear relationships of factor coefficients were significant at $5 \%$ level.

\section{Results}

Advanced milling technology adoption in POMs in Malaysia varied across the process flow chart: sterilization, oil extraction, oil recovery, kernel recovery, boiler operation, and wastewater treatment. However, since the frequencies varied and overlapped, we used the overall incidence of advanced milling technology adoption in the statistical analysis.

\subsection{Descriptive Statistics}

Geographically, Johore and Pahang accounted for the majority of respondents' returns $(61.6 \%)$, which is also because of the concentration of oil palm acreage in these states of Peninsular Malaysia. The descriptive analysis shows that 44.6 of the respondents have had managers posted at a mill for between 6 and 10 years. The operations age showed 57.1\% over 10 years, while $42.9 \%$ have operated for between 2 and 5 years. The size breakdown showed $44.4 \%$ large mills, $40.7 \%$ medium mills, and $14.8 \%$ small mills. The breakdown on quality control certifications was: $97.6 \%$ possess at least one of the ISO 9000, 9001, 14,000 and/or Roundtable on Sustainable Palm Oil (RSPO) certifications.

Table 1 shows a low level of advanced milling technology adoption, ranging from none $(0)$ in oil recovery to $64.8 \%$ in oil extraction. Also, wastewater treatment, boiler operation, and kernel recovery also showed low incidence of adoption of advanced milling technologies. Furthermore, large mills (61.1\%) adopted more than small and medium mills (38.9\%) adopted advanced milling technologies in their operations (Table 2). It would be noted that large mills adopted more than two advanced milling technologies, while small and medium mills adopted one or two of the advanced milling technologies, mainly the second generation of oil extraction technology, in their operations. Therefore, this study defines adopters as those mills that adopted at least one advanced milling technology, while non-adopters adopted none of them (see Table 3).

Table 1. Level of adoption by POMs.

\begin{tabular}{cccc}
\hline Process & Frequency & Mean & Percentage (\%) \\
\hline Sterilization & 26 & 0.48 & 48.1 \\
Oil extraction & 35 & 0.65 & 64.8 \\
Oil recovery & 0 & 0 & 0 \\
Kernel recovery & 18 & 0.33 & 33.3 \\
Boiler operation & 15 & 0.28 & 27.8 \\
Wastewater treatment & 11 & 0.20 & 20.4 \\
\hline
\end{tabular}

Table 2. Adoption of new technology by size of POMs.

\begin{tabular}{cccc}
\hline Adoption of New Milling Technology & SME & Large & N \\
\hline YES 1 & $14(38.9 \%)$ & $21(61.1 \%)$ & 35 \\
NO 0 & $16(84.2 \%)$ & $3(15.8 \%)$ & 19 \\
& 30 & 24 & 54 \\
\hline
\end{tabular}


Table 3. Descriptive statistics of mills based on the adopters and non-adopters.

\begin{tabular}{|c|c|c|c|c|c|c|c|c|c|}
\hline Mill No. & Size & Sterilization & $\begin{array}{c}\text { Oil } \\
\text { Extraction }\end{array}$ & $\begin{array}{c}\text { Oil } \\
\text { Recovery }\end{array}$ & $\begin{array}{c}\text { Kernel } \\
\text { Recovery }\end{array}$ & $\begin{array}{c}\text { Boiler } \\
\text { Operation }\end{array}$ & $\begin{array}{l}\text { Wastewater } \\
\text { Treatment }\end{array}$ & Adopter & $\begin{array}{l}\text { Non- } \\
\text { Adopter }\end{array}$ \\
\hline 1 & large & $x$ & $x$ & - & $x$ & & $x$ & $x$ & \\
\hline 2 & large & - & $X$ & - & & $x$ & $x$ & $x$ & \\
\hline 3 & SME & $x$ & $x$ & - & & & & & \\
\hline 4 & large & $x$ & $x$ & - & $x$ & $x$ & & & \\
\hline 5 & SME & - & - & - & - & - & - & & $\mathrm{x}$ \\
\hline 6 & large & $x$ & $x$ & - & $x$ & $x$ & & & \\
\hline 7 & large & - & $X$ & - & $x$ & & $x$ & $x$ & \\
\hline 8 & SME & - & - & - & - & - & - & & $x$ \\
\hline 9 & large & - & $x$ & - & $x$ & $\mathrm{x}$ & & $x$ & \\
\hline 10 & SME & - & - & - & - & - & - & & $x$ \\
\hline 11 & large & $x$ & $x$ & - & & & & & \\
\hline 12 & SME & - & - & - & - & - & - & & $\mathrm{x}$ \\
\hline 13 & large & $x$ & $x$ & - & $x$ & & $x$ & $x$ & \\
\hline 14 & SME & $x$ & $x$ & - & & & & & \\
\hline 15 & large & - & - & - & - & - & - & & $x$ \\
\hline 16 & SME & - & $x$ & - & & & & & \\
\hline 17 & large & $x$ & $x$ & - & & $x$ & & & \\
\hline 18 & SME & - & - & - & - & - & - & & $x$ \\
\hline 19 & SME & $x$ & $X$ & - & & & & & \\
\hline 20 & large & $x$ & $x$ & - & & & $x$ & $x$ & \\
\hline 21 & large & - & $x$ & - & $x$ & $x$ & & & \\
\hline 22 & SME & - & - & - & - & - & - & & $x$ \\
\hline 23 & SME & $x$ & $x$ & - & & & & & \\
\hline 24 & large & - & - & - & & & & & $x$ \\
\hline 25 & large & $x$ & $x$ & - & & $x$ & $x$ & $x$ & \\
\hline 26 & SME & - & - & - & - & - & - & & $x$ \\
\hline 27 & large & $x$ & $x$ & - & $x$ & & & & \\
\hline 28 & SME & $x$ & $x$ & - & & & & & \\
\hline 29 & large & $x$ & $x$ & - & & $x$ & $x$ & $x$ & \\
\hline 30 & SME & - & - & - & - & - & - & & $x$ \\
\hline 31 & large & $x$ & $x$ & - & $x$ & & & & \\
\hline 32 & SME & - & - & - & - & - & - & & $x$ \\
\hline 33 & large & $x$ & $x$ & - & & $x$ & & & \\
\hline 34 & SME & - & - & - & - & - & - & & $x$ \\
\hline 35 & large & - & $x$ & - & $x$ & & $x$ & $x$ & \\
\hline 36 & large & $x$ & $x$ & - & $x$ & $x$ & & & \\
\hline 37 & large & - & $x$ & - & $x$ & $x$ & & & \\
\hline 38 & SME & - & - & - & - & - & - & & $x$ \\
\hline 39 & large & $x$ & $x$ & - & $x$ & $x$ & & & \\
\hline 40 & SME & - & - & - & - & - & - & & $x$ \\
\hline 41 & large & $x$ & $x$ & - & $x$ & & & & \\
\hline 42 & SME & - & - & - & - & - & - & & $x$ \\
\hline 43 & large & $x$ & $x$ & - & & & $x$ & $x$ & \\
\hline 44 & SME & $x$ & $x$ & - & - & & - & $x$ & \\
\hline
\end{tabular}


Table 3. Cont.

\begin{tabular}{|c|c|c|c|c|c|c|c|c|c|}
\hline Mill No. & Size & Sterilization & $\begin{array}{c}\text { Oil } \\
\text { Extraction }\end{array}$ & $\begin{array}{c}\text { Oil } \\
\text { Recovery }\end{array}$ & $\begin{array}{c}\text { Kernel } \\
\text { Recovery }\end{array}$ & $\begin{array}{c}\text { Boiler } \\
\text { Operation }\end{array}$ & $\begin{array}{l}\text { Wastewater } \\
\text { Treatment }\end{array}$ & Adopter & $\begin{array}{c}\text { Non- } \\
\text { Adopter }\end{array}$ \\
\hline 45 & large & - & - & - & - & - & - & & $x$ \\
\hline 46 & large & $x$ & $x$ & - & & & $x$ & $x$ & \\
\hline 47 & SME & - & - & - & - & - & - & & $x$ \\
\hline 48 & large & $x$ & $x$ & - & $x$ & $x$ & & & \\
\hline 49 & SME & - & - & - & - & - & - & & $x$ \\
\hline 50 & large & $x$ & $x$ & - & $x$ & $x$ & & & \\
\hline 51 & $\mathrm{SME}$ & - & - & - & - & - & - & & $\mathrm{x}$ \\
\hline 52 & $\mathrm{SME}$ & $x$ & $x$ & - & & & & & \\
\hline 53 & large & - & $x$ & - & $x$ & $x$ & & & \\
\hline 54 & large & - & $x$ & - & $x$ & & $x$ & $x$ & \\
\hline
\end{tabular}

\subsection{Model Parameters}

Convergent and discriminant validities were conducted to assess the strength of the measurement model. The results in Table 4 confirm a satisfactory convergent validity parameter on the AVE of all constructs were greater than 0.5 [123]; the factor loadings were above 0.6 [124]; and Cronbach's alpha values for all dimensions of factors are higher than 0.7 [125].

Table 4. Measurement model results.

\begin{tabular}{|c|c|c|c|c|}
\hline Scales & Items & $\begin{array}{l}\text { Factor } \\
\text { Loading }\end{array}$ & AVE & $\begin{array}{l}\text { Cronbach } \\
\text { Alpha }\end{array}$ \\
\hline \multirow{3}{*}{$\begin{array}{l}\text { Complexity } \\
\text { see }[19,126]\end{array}$} & The new technology adoption process is complicated (CX1) & 0.802 & 0.597 & 0.701 \\
\hline & Learning to operate new technology is easy (CX3) & 0.778 & & \\
\hline & New technology usage is understandable (CX2) & 0.736 & & \\
\hline \multirow{3}{*}{$\begin{array}{l}\text { Compatibility } \\
\text { see }[19,126]\end{array}$} & $\begin{array}{l}\text { New technology is compatible with the external } \\
\text { environment (CP3) }\end{array}$ & 0.859 & 0.630 & 0.729 \\
\hline & $\begin{array}{l}\text { New technology is fitting with the current operational } \\
\text { process (CP2) }\end{array}$ & 0.808 & & \\
\hline & $\begin{array}{l}\text { New technology has compatibility with the existing system } \\
\text { of conducting the firm's operation (CP1) }\end{array}$ & 0.705 & & \\
\hline \multirow{2}{*}{$\begin{array}{c}\text { Cost } \\
\text { see }[19,34]\end{array}$} & New technology is expensive to install and maintain (CO2) & 0.823 & 0.649 & 0.771 \\
\hline & New technology is expensive to acquire (CO1) & 0.789 & & \\
\hline \multirow{3}{*}{$\begin{array}{l}\text { Financial resource and support } \\
\text { see }[72,127]\end{array}$} & Lack of adequate capital. (FS3) & 0.827 & 0.653 & 0.802 \\
\hline & lack of financial support (FS2) & 0.812 & & \\
\hline & lack of credits facilities (FS1) & 0.785 & & \\
\hline \multirow{3}{*}{$\begin{array}{l}\text { Top management support } \\
\text { see }[81,103,128]\end{array}$} & $\begin{array}{l}\text { Senior managers involve decision-making on the adoption of } \\
\text { new technology(TM2) }\end{array}$ & 0.831 & 0.623 & 0.830 \\
\hline & $\begin{array}{l}\text { Senior managers support the use of new technology in the } \\
\text { process of production(TM1) }\end{array}$ & 0.805 & & \\
\hline & $\begin{array}{l}\text { Senior managers are likely to be interested in adopting new } \\
\text { technology to gain a competitive advantage (TM3) }\end{array}$ & 0.729 & & \\
\hline
\end{tabular}


Table 4. Cont.

\begin{tabular}{|c|c|c|c|c|}
\hline Scales & Items & $\begin{array}{l}\text { Factor } \\
\text { Loading }\end{array}$ & AVE & $\begin{array}{l}\text { Cronbach } \\
\text { Alpha }\end{array}$ \\
\hline \multirow{3}{*}{$\begin{array}{l}\text { Technical skills } \\
\text { see [86] }\end{array}$} & $\begin{array}{l}\text { Inadequate capacity at the appointed time to obtain technical } \\
\text { knowledge (TS3) }\end{array}$ & 0.819 & 0.516 & 0.721 \\
\hline & $\begin{array}{c}\text { lack of available information in new technology technical } \\
\text { support for managers and employees (TS2) }\end{array}$ & 0.670 & & \\
\hline & $\begin{array}{l}\text { Inadequate technical knowledge and expertise related to } \\
\text { new technology (TS1) }\end{array}$ & 0.655 & & \\
\hline \multirow{2}{*}{$\begin{array}{l}\text { Managers' knowledge } \\
\text { see }[85,129]\end{array}$} & $\begin{array}{l}\text { Top managers have expertise in new technology } \\
\text { practices(MK1) }\end{array}$ & 0.804 & 0.541 & 0.742 \\
\hline & $\begin{array}{c}\text { Top managers have suitable knowledge in advance } \\
\text { technology like POME treatment (MK2) }\end{array}$ & 0.660 & & \\
\hline \multirow{2}{*}{$\begin{array}{l}\text { Size of firm } \\
\text { see }[18,130]\end{array}$} & Number of employees (SF1) & 0.870 & 0.741 & 0.737 \\
\hline & Number of the technical workforce (SF2) & 0.852 & & \\
\hline \multirow{3}{*}{$\begin{array}{l}\text { Environmental pressure } \\
\text { see [86] }\end{array}$} & A large number of mills adopt new technology (EP3) & 0.882 & 0.674 & 0.718 \\
\hline & $\begin{array}{l}\text { Has experienced environmental pressure to adopt new } \\
\text { technology (EP1) }\end{array}$ & 0.807 & & \\
\hline & Most of our competitors use new technology (EP2) & 0.770 & & \\
\hline \multirow{3}{*}{$\begin{array}{l}\text { Government support and policy } \\
\text { see [86] }\end{array}$} & $\begin{array}{l}\text { Inadequate government's new technology policies to create } \\
\text { awareness and promote uptake of the technology (GP3) }\end{array}$ & 0.887 & 0.658 & 0.706 \\
\hline & $\begin{array}{l}\text { Inadequate enforcement of environmental rules by } \\
\text { government officers for adopting new technology } \\
\text { POME (GP1) }\end{array}$ & 0.803 & & \\
\hline & Inadequate subsidies for adopting new technology (GP2) & 0.737 & & \\
\hline \multirow{5}{*}{$\begin{array}{l}\text { Adoption } \\
\text { see [25] }\end{array}$} & Kernel recovery (AD4) & 0.864 & 0.540 & 0.762 \\
\hline & Sterilization (AD1) & 0.830 & & \\
\hline & Boiler operation (AD5) & 0.672 & & \\
\hline & Wastewater treatment (AD6) & 0.639 & & \\
\hline & Oil extraction (AD2) & 0.627 & & \\
\hline
\end{tabular}

Discriminant validity was assessed by the square root of the AVE, as suggested by Fornell and Larcker [131]. The measures of the square root of AVE surpassed the intercorrelations of each variable with the other variables in the model (see Table 5) and, consequently, show an acceptable degree of discriminant validity of all variables.

Due to the existence of several exogenous variables in the framework, this study relies on Kleinbaum et al. [132] and Bowerman and Connell [133] by applying the tolerance test and the variance inflation factor (VIF) to check for multicollinearity. Table 5 shows none violated the recommended values of tolerance and VIF (VIF $<10$ and TL $>0.4$ ), thus demonstrating that multicollinearity is not a concern in this study. 
Table 5. Discriminant validity and collinearity statistics.

\begin{tabular}{|c|c|c|c|c|c|c|c|c|c|c|c|c|c|}
\hline & $C X$ & $\mathrm{CP}$ & $\mathrm{CO}$ & FSR & TMS & MK & TS & SF & EP & GSP & $\mathrm{AD}$ & Tolerance & VIF \\
\hline$C X$ & 0.77 & & & & & & & & & & & 0.654 & 1.529 \\
\hline $\mathrm{CP}$ & -0.25 & 0.79 & & & & & & & & & & 0.515 & 1.941 \\
\hline $\mathrm{CO}$ & $0.44^{* *}$ & -0.23 & 0.80 & & & & & & & & & 0.621 & 1.611 \\
\hline FSR & $0.52 * *$ & $-0.29 *$ & 0.56 ** & 0.80 & & & & & & & & 0.646 & 1.547 \\
\hline TMS & -0.02 & 0.20 & -0.08 & -0.08 & 0.79 & & & & & & & 0.817 & 1.223 \\
\hline MK & $0.39 * *$ & -0.16 & 0.02 & 0.11 & 0.09 & 0.74 & & & & & & 0.590 & 1.696 \\
\hline TS & $0.53^{* *}$ & $-0.34 *$ & $0.30^{*}$ & 0.23 & -0.03 & $0.37^{* *}$ & 0.72 & & & & & 0.635 & 1.576 \\
\hline SF & $-0.68 * *$ & $0.48 * *$ & $-0.71 * *$ & $-0.69 * *$ & 0.13 & -0.23 & $-0.52 * *$ & 0.86 & & & & 0.532 & 1.879 \\
\hline EP & 0.19 & $0.41^{* *}$ & 0.15 & 0.17 & -0.27 & 0.20 & $0.36^{* *}$ & -0.22 & 0.82 & & & 0.749 & 1.334 \\
\hline GSP & $0.36^{* *}$ & $-0.35^{* *}$ & 0.21 & 0.29 * & -0.18 & $0.27^{*}$ & $0.35 * *$ & -0.38 ** & 0.15 & 0.81 & & 0.540 & 1.852 \\
\hline $\mathrm{AD}$ & $-0.44 *$ & 0.23 & $-0.37^{* *}$ & $-0.64^{* *}$ & $0.26^{*}$ & -0.19 & $-0.35^{* *}$ & $0.54 * *$ & -0.22 & $-0.44^{* *}$ & 0.73 & - & - \\
\hline
\end{tabular}

Notes: $\mathrm{CX}=$ complexity, $\mathrm{CP}=$ compatibility, $\mathrm{CO}=$ cost, FSR $=$ financial support and resources, TMS $=$ top management support, $\mathrm{MK}=$ managers' knowledge, $\mathrm{TS}=$ technical skills, $\mathrm{SF}=$ Size of the firm, $\mathrm{EP}=$ environmental pressure, GSP = government support and policy, and AD = adoption. ${ }^{*} p$-value significant at the 0.05 level, ** $p$-value significant at the 0.001 level.

\subsection{Hypotheses Testing}

This study proceeds to examine the research framework and hypotheses by using a logit regression model. Regarding overall discriminating, the results indicate a prediction accuracy of $78.3 \%$ to the overall discriminating power based on the logistic regression model (see Table 6). Since this study includes 35 adopters and 19 non-adopters, calculating the adoption by random selection would lead to $(35 / 54) 2+(19 / 54) 2=54.4 \%$, which is considerably fewer than what is required for the researcher model. As a result, the logistic regression model is given priority over the random selection model due to its much greater discriminatory power.

Table 6. Classification.

\begin{tabular}{ccccc}
\hline & \multirow{2}{*}{ Observed Total } & \multicolumn{2}{c}{ Predicted } & \multirow{2}{*}{ Percentage Correct } \\
\cline { 3 - 4 } & & Adopter & Non-Adopter & \\
\hline Adopter & 35 & 29 & 6 & 82.9 \\
Non-adopter & 19 & 5 & 14 & 73.7 \\
Overall & & & & 78.3 \\
\hline
\end{tabular}

Table 7 indicates that the likelihood ratio test statistic (chi-square $=14.45, \mathrm{df}=3$ and $p=0.002$ ) in the adoption model with the technological predictors fits the data significantly better than the restricted model. The results of the Nagelkerke $R^{2}$ explain that $31.4 \%$ of the variance in the adoption model is explained by the three technology attributes factors of complexity, compatibility, and cost. The -2log likelihood test value was 60.11 , which indicates a strong correlation between the components of technology attributes and new milling technology adoption. The Hosmer-Lemeshow test reports a value $\chi 2=4.01$ and the $p$-value $(p<0.675)$, thus confirming an overall good fit for the adoption model at significant level $5 \%$.

The statistical significance of the hypothesized technology attributes variables together with their regression coefficients and Wald statistics indicate that the critical factors of complexity and cost with $p$-values of 0.013 and 0.011 respectively are significant predictors for adoption of advanced milling technologies at the $5 \%$ level, which therefore support the hypotheses, $\mathrm{H} 2$ and $\mathrm{H} 3$. The negative value of factors of complexity $(-1.705)$ and cost $(-1.780)$ in Table 6 show that mill managers who recognize that advanced milling technologies were complicated and costly with $p$-values of 0.182 and 0.169 , respectively, are not significant predictors of adoption of advanced milling technologies. Compatibility 
( $p$-value $>0.05$ ) is an insignificant predictor of advanced milling technology adoption with a coefficient of 0.976 , and hence, $\mathrm{H} 1$ should be rejected.

Table 7. Logistic regression analysis model of technology attributes.

\begin{tabular}{|c|c|c|c|c|c|c|c|c|}
\hline \multirow{2}{*}{ Predictor } & \multirow[t]{2}{*}{ B } & \multirow{2}{*}{ S.E } & \multirow{2}{*}{ Wald } & \multirow{2}{*}{ df } & \multirow{2}{*}{ Sig. } & \multirow{2}{*}{$\begin{array}{l}\text { Odds } \\
\text { Ratio }\end{array}$} & \multicolumn{2}{|c|}{$\begin{array}{l}\text { 95\% C.I. for Odds } \\
\text { Ratio }\end{array}$} \\
\hline & & & & & & & Lower & Upper \\
\hline Compatibility & 0.976 & 0.640 & 2.326 & 1 & 0.127 & 2.653 & 0.757 & 9.294 \\
\hline Complexity & -1.705 & 0.686 & 6.182 & 1 & 0.013 & 0.182 & 0.047 & 0.697 \\
\hline Cost & -1.780 & 0.698 & 6.498 & 1 & 0.011 & 0.169 & 0.043 & 0.663 \\
\hline Constant & 1.532 & 0.717 & 4.570 & 1 & 0.033 & 4.627 & & \\
\hline \multicolumn{9}{|l|}{ Overall Model Evaluation } \\
\hline Test & \multicolumn{3}{|c|}{ Chi-Squared } & \multicolumn{3}{|c|}{ Df } & \multicolumn{2}{|c|}{$p$-Value } \\
\hline Likelihood Test & \multirow{2}{*}{\multicolumn{3}{|c|}{14.449}} & \multirow{2}{*}{\multicolumn{3}{|c|}{3}} & \multicolumn{2}{|c|}{0.002} \\
\hline Goodness-of-Fit Test & & & & & & & & \\
\hline Homer-Lemeshow Test & \multicolumn{3}{|c|}{4.013} & \multicolumn{3}{|c|}{6} & \multicolumn{2}{|c|}{0.675} \\
\hline-2 Logistic likelihood & \multicolumn{8}{|c|}{60.115} \\
\hline Cox and Snell's R Squared & \multicolumn{8}{|c|}{0.235} \\
\hline Nagelkerke R Squared & \multicolumn{8}{|c|}{0.314} \\
\hline
\end{tabular}

$$
\begin{gathered}
\operatorname{Ln} \frac{P}{1-P}=1.532-1.705 X 2-1.780 X 3 \\
\mathrm{E}(Y 1)=\mathrm{e}^{\Upsilon 1} /\left(1+\mathrm{e}^{\Upsilon 1}\right)
\end{gathered}
$$

Therefore, the logistic regression model was presented in the form of the logarithmic equation (Equation (4)) and the logistic response function E(Y1) (Equation (5)) for adoption of advanced milling technology affected by the technology attributes, where $\mathrm{X} 2=$ complexity and $\mathrm{X} 3=$ cost.

The logistic response function $\mathrm{E}(Y 1)$ (Equation (5)) is used to calculate the probability of $Y 1$ occurring of advanced milling technology adopted by a firm; for instance, in the case that a milling firm has complexity $[X 2(1)=1]$, and cost $[X 3(1)=1], \mathrm{E}(Y 1)$ equals to 0.124 , which is close to 0 . It implies that a milling firm having these characteristics has a $12.4 \%$ probability of adopting new milling technology.

The results of the likelihood ratio test statistic (chi-square $=19.87, \mathrm{df}=5$ and $p=0.001$ ) in Table 8 presents that the adoption model of advanced milling technology with organizational determining factors is significantly more reliable than the fixed model alone. The results Nagelkerke $R^{2}$ model shows that the five organizational factors explained $41.1 \%$ of the variation in the adoption model of advanced milling technologies. At $-2 \mathrm{Log}$ likelihood $=54.69$, the adoption model satisfactorily fits the investigation data. Moreover, Hosmer-Lemeshow chi-square test statistic (Chi $=4.980, \mathrm{df}=5, p=0.662)$ shows that the data fits the model well. 
Table 8. Logistic Regression analysis model of organizational factors.

\begin{tabular}{|c|c|c|c|c|c|c|c|c|}
\hline \multirow{2}{*}{ Predictor } & \multirow[t]{2}{*}{ B } & \multirow[t]{2}{*}{ S.E } & \multirow{2}{*}{ Wald } & \multirow[t]{2}{*}{ df } & \multirow{2}{*}{ Sig. } & \multirow{2}{*}{$\begin{array}{l}\text { Odds } \\
\text { Ratio }\end{array}$} & \multicolumn{2}{|c|}{$\begin{array}{c}\text { 95\% C.I. for Odds } \\
\text { Ratio }\end{array}$} \\
\hline & & & & & & & Lower & Upper \\
\hline Financial support & -1.860 & 0.841 & 4.886 & 1 & 0.027 & 0.156 & 0.030 & 0.810 \\
\hline Top management support & 1.778 & 0.881 & 4.070 & 1 & 0.044 & 5.920 & 1.052 & 33.311 \\
\hline Managers' knowledge & -0.979 & 0.694 & 1.987 & 1 & 0.159 & 0.376 & 0.096 & 1.465 \\
\hline Technical skills & -1.823 & 0.763 & 5.704 & 1 & 0.017 & 0.162 & 0.036 & 0.721 \\
\hline Size of the firm & 1.647 & 0.758 & 4.720 & 1 & 0.030 & 5.189 & 1.175 & 22.920 \\
\hline Constant & 1.004 & 0.738 & 1.850 & 1 & 0.174 & 2.728 & & \\
\hline \multicolumn{9}{|l|}{ Overall Model Evaluation } \\
\hline Test & \multicolumn{3}{|c|}{ Chi-Squared } & \multicolumn{3}{|c|}{ dfDf } & \multicolumn{2}{|c|}{$p$-Value } \\
\hline Likelihood Test & \multirow{2}{*}{\multicolumn{3}{|c|}{19.868}} & \multirow{2}{*}{\multicolumn{3}{|c|}{5}} & \multirow{2}{*}{\multicolumn{2}{|c|}{0.001}} \\
\hline Goodness-of-Fit Test & & & & & & & & \\
\hline Homer \& Lemeshow Test & \multicolumn{3}{|c|}{4.980} & \multicolumn{3}{|c|}{7} & \multicolumn{2}{|c|}{0.662} \\
\hline-2 Logistic likelihood & \multicolumn{8}{|c|}{54.696} \\
\hline Cox and Snell's R Squared & \multicolumn{8}{|c|}{0.308} \\
\hline Nagelkerke R Squared & \multicolumn{8}{|c|}{0.411} \\
\hline
\end{tabular}

Financial support, top management support, human capital with technical skills, and size of the firm were the results of the organizational critical factors of advanced milling technologies that were significant at $p$-Value $<0.05$, which support the hypotheses, H4, H5, H7, and H8 respectively (Table 8). Managers' knowledge was not a statistically significant predictor of advanced milling technologies, which calls for the rejection of hypothesis H6.

Consequently, the study proceeded with the logistic regression model in the form of logarithmic Equation (6), and the logistic response function E (Y2) (Equation (7)) on organizational factors for the adoption of advanced milling technology:

$$
\begin{gathered}
\operatorname{Ln} \frac{P}{1-P}=1.004-1.860 X 1+1.778 X 2-1.823 X 4+1.647 X 5 \\
\mathrm{E}(Y 2)=\mathrm{e}^{\Upsilon 2} /\left(1+\mathrm{e}^{\Upsilon 2}\right)
\end{gathered}
$$

where $X 1=$ financial support $/$ resource, $X 2=$ top management support, $X 4=$ technical skills, and $X 5=$ mill size. In the case that a mill firm enjoys financial support and resources $[X 1(1)=1]$, top management support $[X 2(1)=1]$, technical skills $[X 4(1)=1]$ and is a large mill $[X 5(1)=1], E(Y 2)$ shall equal 0.678 , which is close to 1 . It means that a mill endowed with these characteristics has a $67.8 \%$ probability of adopting advanced milling technology. Similarly, when mill size is small [X5(1) = 0], E $(Y 2)$ is accounted for 0.288, which implies that a small mill with all these specifications has a $28.8 \%$ probability of adopting advanced milling technology.

The likelihood ratio test statistics (Table 9) shows that the adoption model with the environmental factors fits the data significantly better than the fixed only model (chi-square $=7.10, \mathrm{df}=2$ and $p=0.029$ ). The Nagelkerke $R^{2}$ model results show that $16.5 \%$ of the variation in the advanced milling technologies adoption models is accounted for by the two environmental factors. The $-2 \log$ likelihood value was 67.46 , indicating that the model fits well the study data. The Hosmer-Lemeshow test $(\chi 2=1.54, p$-value $=0.464)$ indicates that the adoption model by the two determining factors is a suitable model fit at $5 \%$ level of significance. 
Table 9. Logistic regression analysis model of environmental factors.

\begin{tabular}{|c|c|c|c|c|c|c|c|c|}
\hline \multirow{2}{*}{ Predictor } & \multirow[t]{2}{*}{ B } & \multirow{2}{*}{ S.E } & \multirow{2}{*}{ Wald } & \multirow[t]{2}{*}{ df } & \multirow{2}{*}{ Sig. } & \multirow{2}{*}{$\begin{array}{l}\text { Odds } \\
\text { Ratio }\end{array}$} & \multicolumn{2}{|c|}{$\begin{array}{c}\text { 95\% C.I. for Odds } \\
\text { Ratio }\end{array}$} \\
\hline & & & & & & & Lower & Upper \\
\hline Environment pressure & -0.333 & 0.585 & 0.323 & 1 & 0.570 & 0.717 & 0.228 & 2.257 \\
\hline Government support & -1.473 & 0.604 & 5.948 & 1 & 0.015 & 0.229 & 0.070 & 0.749 \\
\hline Constant & 1.193 & 0.551 & 4.686 & 1 & 0.030 & 3.296 & & \\
\hline \multicolumn{9}{|l|}{ Overall Model Evaluation } \\
\hline Test & \multicolumn{3}{|c|}{ Chi-Squared } & \multicolumn{3}{|c|}{ dfDf } & \multicolumn{2}{|c|}{$p$-Value } \\
\hline Likelihood Test & \multirow{2}{*}{\multicolumn{3}{|c|}{7.104}} & \multirow{2}{*}{\multicolumn{3}{|c|}{2}} & \multicolumn{2}{|c|}{0.029} \\
\hline Goodness of-Fit Test & & & & & & & & \\
\hline Homer \& Lemeshow Test & \multicolumn{3}{|c|}{1.536} & \multicolumn{3}{|c|}{2} & \multicolumn{2}{|c|}{0.464} \\
\hline -2 Logistic likelihood & \multicolumn{8}{|c|}{67.459} \\
\hline Cox and Snell's R Squared & \multicolumn{8}{|c|}{0.123} \\
\hline Nagelkerke R Squared & \multicolumn{8}{|c|}{0.165} \\
\hline
\end{tabular}

The results in Table 9 show that environmental pressure is statistically insignificant at the $5 \%$ alpha level, and hence, call for the rejection of hypothesis H9. In contrast, government support has a negative and significant influence on adopting advanced milling technologies at the $5 \%$ level, which lends support for hypothesis H10. The results allows the pursuit of the following logit regression:

$$
\begin{gathered}
\operatorname{Ln} \frac{P}{1-P}=1.193-1.473 \text { government support } \\
\mathrm{E}(Y 3)=\mathrm{e}^{Y 3} /\left(1+\mathrm{e}^{Y 3}\right)
\end{gathered}
$$

In case that a mill has government support $(-1.476) \mathrm{E}(Y 3)$ is equivalent to 0.430 , which implies that a mill with a lack of government support has $43 \%$ probability of adopting a new milling technology.

\section{Discussion}

The TOE-DOI framework produced interesting and statistically significant results for explaining the rationale behind why some POMs adopted advanced milling technologies while others did not. This study found that organizational factors have a stronger influence on the adoption of advanced milling technologies by Malaysian POMs than technology attributes and environmental factor. The findings of Henriksen [134] who used the TOE framework in the Danish steel and machinery industry, which concur with the importance of the organizational factors; it also found the environmental factors as more important than technology attributes.

Three components were captured in the technology attributes construct, namely, complexity, compatibility, and cost. Complexity and cost showed significant negative coefficients and lent support to $\mathrm{H} 1$ and $\mathrm{H} 3$. A possible justification for these results is that when compared to conventional milling technologies, modern technologies (such as multiple screw presses) have caused malfunctions in POMs owing to irregular maintenance support and complexity of advanced milling technologies [135], especially among POMs that have installed complex milling technologies. These findings are in sync with previous findings who found complexity and cost critical in the adoption of advanced technologies e.g., $[26,27,30,31,36,41]$.

Interviews with the managers show that mill managers should take the initiative to coordinate with suppliers to make the machinery user-friendly and simplify the maintenance procedures. Indeed, mills equipped with managers and skillful technicians play a key role in shortening downtime in the use of advanced milling technologies. Indeed, the large firms, such as Sime Darby have highly qualified technical personnel who in addition 
to solving problems, are also engaged in minor process $\mathrm{R}$ and $\mathrm{D}$ activities in coordination with suppliers to modify machinery to make them user friendly.

Hypothesis $\mathrm{H} 1$ was not supported as compatibility showed a statistically insignificant relationship with the adoption of advanced milling technology, which is not in sync with the findings of several studies $[36,37,84]$, who argue that the adoption of technology depended on the degree of compatibility perceived. This abnormal finding could be a consequence of a disjuncture between what managers perceive and actual decisions made on acquiring advanced milling technologies, suggesting that a more extensive and rigorous study is essential.

Financial support and resources, top management support, managers' knowledge, technical skills, and size were the influences captured in the organizational construct. Financial support and resources showed a significant relationship with adoption of new milling technology (Hypothesis H4), which concurs with several findings [36,42,71]. Milling machinery requires heavy capital investment, and hence, it is not in the range of firms that lack sufficient finances. Consequently, some small POMs have overcome this barrier by pooling resources through collaboration with integrated plantation companies and small private millers $[33,136]$.

Top management support was statistically significant in the adoption of advanced milling technology (Hypothesis H5), which strengthens several past findings e.g., [35,36,71]. Managers' knowledge of advanced milling technologies was not significant (Hypothesis H6), which is likely as top management makes key decisions when involving lumpy investments. This finding is not in line with many previous findings e.g., $[9,71,85,86]$ that emphasize that managers' knowledge significantly influences technology adoptions. Managers and engineers tend to focus on processes and production matters, such as extraction efficiencies, product qualities, product losses, and process energy efficiencies. Also, interviews show that mill managers and technicians tend to be focused on their day-to-day tasks of operating and maintaining existing machinery see also [137].

The importance of technical personnel is demonstrated by the significant relationship between human capital with technical skills and adoption of advanced milling technologies (Hypothesis H7), which is consistent with the findings of Abdullah et al. [85], Holzl and Janger [138], Baluch, Abdullah, and Mohtar [139], Silva et al. [140], and Perron [141]. Organized trainings, including specialized skill development training and external training that involve both technical personnel and management, can be a solution for improving the technical skills required to support advanced milling technologies. Milling firms reported enjoying access to free education programs, training, and workshops provided by machinery suppliers.

A firm's size was a critical factor in POMs' adoption of advanced milling technologies and substantially supported hypothesis H8, which confirms previous findings that found firm size as a significant influence on the adoption of new technology [37,42,98,100]. Small firms tend to lack the requisite resources, including financial funds, assets, and in-house technical skills, and hence, often avoid investing in complex and expensive machinery $[96,103,142]$. This finding is also in sync with the argument of the pioneer of the concept of innovation [143] who argued that larger firms are more likely to engage in risky and uncertain activities than small firms.

Comparing the mean ranks of these factors between adopters and non-adopters, we found significant differences $(p<0.05)$ with the critical factors that show negative coefficients, which pose fewer barriers to adopters than to non-adopters. At the same time, top management support was the most critical driver among non-adopters, but not with adopters (see Table 10). 
Table 10. Mann-Whitney U Tests for adopters and non-adopters differences.

\begin{tabular}{|c|c|c|c|c|c|c|c|c|}
\hline \multicolumn{5}{|c|}{ Ranks } & \multicolumn{4}{|c|}{ Test Statistics } \\
\hline & & $\mathbf{N}$ & Mean Rank & Sum of Ranks & Mann-Whitney U & $\begin{array}{l}\text { Wilcoxon } \\
\text { W }\end{array}$ & $\mathrm{Z}$ & $\begin{array}{c}\text { Asymp. Sig. } \\
\text { (2-Tailed) }\end{array}$ \\
\hline $\mathrm{CP} 1$ & $\begin{array}{l}\text { Non-Adopters } \\
\text { Adopters } \\
\text { Total }\end{array}$ & $\begin{array}{l}19 \\
35 \\
54\end{array}$ & $\begin{array}{l}29.82 \\
26.24\end{array}$ & $\begin{array}{l}566.50 \\
918.50\end{array}$ & 288.500 & 918.500 & -1.008 & 0.314 \\
\hline $\mathrm{CP} 2$ & $\begin{array}{l}\text { Non-Adopters } \\
\text { Adopters } \\
\text { Total }\end{array}$ & $\begin{array}{l}19 \\
35 \\
54\end{array}$ & $\begin{array}{l}23.92 \\
29.44\end{array}$ & $\begin{array}{c}454.50 \\
1030.50\end{array}$ & 264.500 & 454.500 & -1.415 & 0.157 \\
\hline $\mathrm{CP} 3$ & $\begin{array}{l}\text { Non-Adopters } \\
\text { Adopters } \\
\text { Total }\end{array}$ & $\begin{array}{l}19 \\
35 \\
54\end{array}$ & $\begin{array}{l}26.63 \\
27.97\end{array}$ & $\begin{array}{l}506.00 \\
979.00\end{array}$ & 316.000 & 506.000 & -0.354 & 0.723 \\
\hline CX2 & $\begin{array}{l}\text { Non-Adopters } \\
\text { Adopters } \\
\text { Total }\end{array}$ & $\begin{array}{l}19 \\
35 \\
54\end{array}$ & $\begin{array}{l}33.37 \\
24.31\end{array}$ & $\begin{array}{l}634.00 \\
851.00\end{array}$ & 221.000 & 851.000 & -2.895 & 0.004 \\
\hline CX1 & $\begin{array}{l}\text { Non-Adopters } \\
\text { Adopters } \\
\text { Total }\end{array}$ & $\begin{array}{l}19 \\
35 \\
54\end{array}$ & 20.76 & $\begin{array}{c}394.50 \\
1090.50\end{array}$ & 204.500 & 394.500 & -2.724 & 0.006 \\
\hline CX3 & $\begin{array}{l}\text { Non-Adopters } \\
\text { Adopters } \\
\text { Total }\end{array}$ & $\begin{array}{l}19 \\
35 \\
54\end{array}$ & $\begin{array}{l}20.42 \\
31.34\end{array}$ & $\begin{array}{l}388.00 \\
1097.00\end{array}$ & 198.000 & 388.000 & -2.592 & 0.010 \\
\hline $\mathrm{CO} 1$ & $\begin{array}{l}\text { Non-Adopters } \\
\text { Adopters } \\
\text { Total }\end{array}$ & $\begin{array}{l}19 \\
35 \\
54\end{array}$ & $\begin{array}{l}19.24 \\
31.99\end{array}$ & $\begin{array}{c}365.50 \\
1119.50\end{array}$ & 175.500 & 365.500 & -3.078 & 0.002 \\
\hline $\mathrm{CO} 2$ & $\begin{array}{l}\text { Non-Adopters } \\
\text { Adopters } \\
\text { Total }\end{array}$ & $\begin{array}{l}19 \\
35 \\
54\end{array}$ & $\begin{array}{l}21.63 \\
30.69\end{array}$ & $\begin{array}{c}411.00 \\
1074.00\end{array}$ & 221.000 & 411.000 & -2.203 & 0.028 \\
\hline FSR1 & $\begin{array}{l}\text { Non-Adopters } \\
\text { Adopters } \\
\text { Total }\end{array}$ & $\begin{array}{l}19 \\
35 \\
54\end{array}$ & $\begin{array}{l}35.53 \\
23.14\end{array}$ & $\begin{array}{l}675.00 \\
810.00\end{array}$ & 180.000 & 810.000 & -3.208 & 0.001 \\
\hline FSR3 & $\begin{array}{l}\text { Non-Adopters } \\
\text { Adopters } \\
\text { Total }\end{array}$ & $\begin{array}{l}19 \\
35 \\
54\end{array}$ & $\begin{array}{l}33.37 \\
24.31\end{array}$ & $\begin{array}{l}634.00 \\
851.00\end{array}$ & 221.000 & 851.000 & -2.895 & 0.004 \\
\hline FSR2 & $\begin{array}{l}\text { Non-Adopters } \\
\text { Adopters } \\
\text { Total }\end{array}$ & $\begin{array}{l}19 \\
35 \\
54\end{array}$ & $\begin{array}{l}30.85 \\
25.53\end{array}$ & $\begin{array}{l}617.00 \\
868.00\end{array}$ & 229.500 & 859.500 & -2.139 & 0.032 \\
\hline TMS1 & $\begin{array}{l}\text { Non-Adopters } \\
\text { Adopters } \\
\text { Total }\end{array}$ & $\begin{array}{l}19 \\
35 \\
54\end{array}$ & $\begin{array}{l}22.29 \\
30.33\end{array}$ & $\begin{array}{l}423.50 \\
1061.50\end{array}$ & 233.500 & 423.500 & -2.051 & 0.040 \\
\hline TMS2 & $\begin{array}{l}\text { Non-Adopters } \\
\text { Adopters } \\
\text { Total }\end{array}$ & $\begin{array}{l}19 \\
35 \\
54\end{array}$ & $\begin{array}{l}21.89 \\
30.54\end{array}$ & $\begin{array}{l}416.00 \\
1069.00\end{array}$ & 226.000 & 416.000 & -2.279 & 0.023 \\
\hline TMS3 & $\begin{array}{l}\text { Non-Adopters } \\
\text { Adopters } \\
\text { Total }\end{array}$ & $\begin{array}{l}19 \\
35 \\
54\end{array}$ & $\begin{array}{l}20.03 \\
31.56\end{array}$ & $\begin{array}{c}380.50 \\
1104.50\end{array}$ & 190.500 & 380.500 & -2.804 & 0.005 \\
\hline MK1 & $\begin{array}{l}\text { Non-Adopters } \\
\text { Adopters } \\
\text { Total }\end{array}$ & $\begin{array}{l}19 \\
35 \\
54\end{array}$ & $\begin{array}{l}30.26 \\
26.00\end{array}$ & $\begin{array}{l}575.00 \\
910.00\end{array}$ & 280.000 & 910.000 & -1.110 & 0.267 \\
\hline MK2 & $\begin{array}{l}\text { Non-Adopters } \\
\text { Adopters } \\
\text { Total }\end{array}$ & $\begin{array}{l}19 \\
35 \\
54\end{array}$ & $\begin{array}{l}25.58 \\
28.54\end{array}$ & $\begin{array}{l}486.00 \\
999.00\end{array}$ & 296.000 & 486.000 & -0.810 & 0.418 \\
\hline TS2 & $\begin{array}{l}\text { Non-Adopters } \\
\text { Adopters } \\
\text { Total }\end{array}$ & $\begin{array}{l}19 \\
35 \\
54\end{array}$ & $\begin{array}{l}20.24 \\
31.44\end{array}$ & $\begin{array}{c}384.50 \\
1100.50\end{array}$ & 194.500 & 384.500 & -2.937 & 0.003 \\
\hline TS1 & $\begin{array}{l}\text { Non-Adopters } \\
\text { Adopters } \\
\text { Total }\end{array}$ & $\begin{array}{l}19 \\
35 \\
54\end{array}$ & $\begin{array}{l}22.13 \\
30.41\end{array}$ & $\begin{array}{c}420.50 \\
1064.50\end{array}$ & 230.500 & 420.500 & -2.072 & 0.038 \\
\hline TS3 & $\begin{array}{l}\text { Non-Adopters } \\
\text { Adopters } \\
\text { Total }\end{array}$ & $\begin{array}{l}19 \\
35 \\
54\end{array}$ & $\begin{array}{l}21.00 \\
31.03\end{array}$ & $\begin{array}{c}399.00 \\
1086.00\end{array}$ & 209.000 & 399.000 & -2.687 & 0.007 \\
\hline SF1 & $\begin{array}{l}\text { Non-Adopters } \\
\text { Adopters } \\
\text { Total }\end{array}$ & $\begin{array}{l}19 \\
35 \\
54\end{array}$ & $\begin{array}{l}19.76 \\
31.70\end{array}$ & $\begin{array}{c}375.50 \\
1109.50\end{array}$ & 185.500 & 375.500 & -3.093 & 0.002 \\
\hline SF2 & $\begin{array}{l}\text { Non-Adopters } \\
\text { Adopters } \\
\text { Total }\end{array}$ & $\begin{array}{l}19 \\
35 \\
54\end{array}$ & $\begin{array}{l}21.37 \\
30.83\end{array}$ & $\begin{array}{c}406.00 \\
1079.00\end{array}$ & 216.000 & 406.000 & -2.312 & 0.021 \\
\hline EP1 & $\begin{array}{l}\text { Non-Adopters } \\
\text { Adopters } \\
\text { Total }\end{array}$ & $\begin{array}{l}19 \\
35 \\
54\end{array}$ & $\begin{array}{l}30.58 \\
25.83\end{array}$ & $\begin{array}{l}581.00 \\
904.00\end{array}$ & 274.000 & 904.000 & -1.135 & 0.256 \\
\hline EP2 & $\begin{array}{l}\text { Non-Adopters } \\
\text { Adopters } \\
\text { Total }\end{array}$ & $\begin{array}{l}19 \\
35 \\
54\end{array}$ & $\begin{array}{l}29.89 \\
26.20\end{array}$ & $\begin{array}{l}568.00 \\
917.00\end{array}$ & 287.000 & 917.000 & -0.904 & 0.366 \\
\hline EP3 & $\begin{array}{l}\text { Non-Adopters } \\
\text { Adopters } \\
\text { Total }\end{array}$ & $\begin{array}{l}19 \\
35 \\
54\end{array}$ & $\begin{array}{l}28.84 \\
26.77\end{array}$ & $\begin{array}{l}548.00 \\
937.00\end{array}$ & 307.000 & 937.000 & -0.525 & 0.600 \\
\hline GSP1 & $\begin{array}{l}\text { Non-Adopters } \\
\text { Adopters } \\
\text { Total }\end{array}$ & $\begin{array}{l}19 \\
35 \\
54\end{array}$ & $\begin{array}{l}20.97 \\
31.04\end{array}$ & $\begin{array}{c}398.50 \\
1086.50\end{array}$ & 208.500 & 398.500 & -2.564 & 0.010 \\
\hline GSP2 & $\begin{array}{l}\text { Non-Adopters } \\
\text { Adopters } \\
\text { Total }\end{array}$ & $\begin{array}{l}19 \\
35 \\
54\end{array}$ & $\begin{array}{l}22.21 \\
30.37\end{array}$ & $\begin{array}{c}422.00 \\
1063.00\end{array}$ & 232.000 & 422.000 & -2.346 & 0.019 \\
\hline GSP3 & $\begin{array}{l}\text { Non-Adopters } \\
\text { Adopters } \\
\text { Total }\end{array}$ & $\begin{array}{l}19 \\
35 \\
54\end{array}$ & $\begin{array}{l}21.53 \\
30.74\end{array}$ & $\begin{array}{c}409.00 \\
1076.00\end{array}$ & 219.000 & 409.000 & -2.289 & 0.022 \\
\hline
\end{tabular}

The environmental construct examined the relationship between environmental pressures driven at protecting the environment and subsequent government involvement in supporting installation of greening measures by milling firms. Environment pressures had 
an insignificant negative coefficient, and hence, hypothesis $\mathrm{H} 9$ was not supported. Three reasons explain why environmental pressures have had little impact on the adoption of advanced milling technologies. Interviews show that the adopters were largely motivated by yields offered by the new technology as there have been little efforts to enforce these pressures in firms, especially when the output is directed at Asian and African markets. In fact, most of these firms are still using second generation milling technologies. Furthermore, crude palm oil prices were generally low over the period 2015-17, which did not justify investment in new technology. Only the large integrated firms largely sought to introduce new technologies as it offered them technological benefits (see also [37,105]).

Unlike environmental pressure, government support had a significant negative coefficient, which supports Hypothesis H10, which implies that government incentives and financing mechanisms are insufficient to encourage Malaysian mill firms to venture into advanced technologies, especially among non-adopters than among adopters. Generally, the most critical obstacle to taking environmental protection action is lack of financial support [144]. Therefore, the Malaysian government should provide more financial support and incentives in the forms of subsidy, low-interest loans, tax exemption, cost of funds for using advanced milling technologies, and to also more tighten controls and pressures for firms to comply with POME discharge standards of RSPO. This finding concurs with several other studies that found a lack of government support to have affected the adoption of technology e.g., [28,85,86,105,114,145].

\section{Conclusions}

Advanced milling technologies are complex and varied such that a single adoption framework will not be effective. These technologies are costly, require high maintenance expenditure, and are part of integrated mechanisms that offer palm oil mills competitive advantage if they are carefully identified and managed. Technologies in advanced palm oil milling comprise a variety of aspects, including advanced oil extraction and recovery machinery, high-efficiency boilers, and high rate anaerobic digestion processors for raising oil extraction yields, CPO quality, and lowering oil losses, POME pollution controls, which are critical in increasing mill productivity while addressing climate change and global warming issues. Indeed, it is pertinent that all oil palm mills increase their focus on greening and sustainability issues not just to sustain exports but also contribute global initiatives under the United States Convention for Climate Change (UNFCCC) to mitigate climate change and global warming.

This study seeks to extend adoption knowledge by the use of developing a 10-factor model for advanced milling technology adoption through an integrated TOE/DOI framework; by evaluating the framework to specify the power of the determinants to nonadopters and adopters. The hypothetical constructs accompanied by significant negative coefficients include complexity, cost, financial support and resources, technical skills, and government support, which have been critical adoption factors. However, these variables have hindered adopters less than the non-adopters. Top management support and firm size were significant determinants of adoption. In contrast, compatibility, managers' knowledge, and environmental pressure were not significant critical factors of adoption. Consequently, organizational constructs had more impact on the adoption of advanced milling technology than technological and environmental constructs.

The study tested and validated the proposed framework, which showed statistically significant relationships between T-O-E factors and the adoption of advanced milling technologies. Consequently, the results offer a strong theoretical basis for the adoption of advanced milling technologies in the palm oil industry in Malaysia. It also replicates past findings on the influence of cost factors in the installation and maintenance of new milling technologies. Whereas complexity, top management support, technical skill, and firm size were the most critical factors for adopters, government support was not significant, though firms unanimously noted that it was only because of a lack of coordination between government authorities (including incentives) and firms. 
The results provide important implications for policymakers, mill CEOs, managers, and practitioners. To increase adoption of advanced milling technologies, policymakers should focus on eliminating barriers by taking a stand against inappropriate strategies and by providing supportive subsidies that motivate investment in advanced milling technologies, especially for small and medium mills as size and related factors pose significant adoption challenges. Small and medium mills seldom leverage the strengths of extended functions of second-generation milling technologies since they lack the financial muscle to absorb the risks of adopting innovative and complex milling technologies.

Policymakers, mills' CEOs and managers, advanced milling technology investors, and suppliers must collaborate to cocreate a sustainable innovative technology economy that motivates both the demand and supply of the advanced milling technologies. However, to achieve sustainable development objectives in Malaysian POMs, demand for advanced milling technology would require more than significant policy structures. Sufficient investment is needed to support mill firms to obtain technical support to improve the capability of technicians and to enhance the probability of POMs to adopt advanced milling technologies. For advanced milling technologies to act as a catalyst to achieve sustainable development, the government has to prioritize tax incentives (such as the investment tax allowance) for mill firms that invest in costly advanced milling technologies.

Furthermore, mill owners and managers should place more attention on evaluating the internal and external barriers that can influence their decision to adopt particular milling technologies and to implement proper strategies. The evidence on internal barriers to advanced milling technology adoption also provides a rationale for collaboration with industry, MPOB, and universities to generate commercial data to help address gaps that create uncertainties associated with new technology adoption.

As with any study, we suggest the following directions for future research in the area. First, the study relied on a binary approach (adopted or not adopted), and hence, future studies should address the stages of adoption or adopted, rejected, and post-adoption to strengthen the dynamics of adoption. Second, other critical decision factors, which may impact adoption of advanced milling technologies should become important areas to focus on in the future. Third, a panel study may be needed to strengthen the causality relationships established in this study.

Author Contributions: Conceptualization, S.P.; methodology, S.P.; supervision, R.R.; writingoriginal draft, S.P.; writing-review and editing, R.R. and S.P. All authors have read and agreed to the published version of the manuscript.

Funding: This research received no external funding.

Institutional Review Board Statement: Not Applicable.

Informed Consent Statement: Informed consent was obtained from all subjects involved in the study.

Data Availability Statement: Not applicable.

Conflicts of Interest: The authors declare no conflict of interest.

\section{References}

1. Begum, H.; Alam, A.S.A.F.; Er, A.C.; Ghani, A.B.A. Environmental sustainability practices among palm oil millers. Clean Technol. Environ. Policy 2019, 21, 1979-1991. [CrossRef]

2. MPOB. Overview of the Malaysian Oil Palm Industry. 2019. Available online: http://bepi.mpob.gov.my/images/overview/ Overview_of_Industry_2019.pdf (accessed on 23 June 2019).

3. Gan, P.Y.; Li, Z.D. Econometric study on Malaysia's palm oil position in the world market to 2035. Renew. Sustain. Energy Rev. 2014, 39, 740-747. [CrossRef]

4. Tai-Yue, W.; Shih-Chien, C. The Influences of Technology Development on Economic Performance-The Example of ASEAN Countries. Technovation 2007, 27, 471-488.

5. Jin, Z. Soft Technology-The Essential of Innovation. Futures Res. Q. 2002, 18, 1-24.

6. Karlsson, C.; Taylor, M.; Taylor, A. Integrating new technology in established organizations: A mapping of integration mechanisms. Int. J. Oper. Prod. Manag. 2010, 30, 672-699. [CrossRef] 
7. Mat, A.; Razak, R.C. Empirical Research on the Relationship between Organizational Learning Capability and Success of Technological Product Innovation Implementation in Electrical and Electronics Sector. Aust. J. Basic Appl. Sci. $2011,5,730-738$.

8. Hassan, A.; Muhammad, N.H.; Ab Rahman, Z.; Halim, R.M.; Alias, H.; Sabtu, M. Improving Mill Oil Extraction Rate under the Malaysian National Key Economic Area. Palm Oil Eng. 2012, 103, 32-47.

9. Yahaya, S.M.; Lau, S. Palm oil mill effluent (POME) from Malaysia palm oil mills: Waste or resource. Int. J. Sci. Environ. Technol. 2013, 2, 1138-1155.

10. Pawanchik, A.; Sulaiman, S. Alpha Catalyst Consulting. In Search of InnovAsian: The Malaysian Innovation Climate Report 2010 2010. Available online: https:/ /www.alphacatalyst.com/uploads/4/5/6/0/45601163/accmalaysianinnovationclimatereport2 010-100208204939-phpapp01.pdf (accessed on 25 January 2010).

11. Jayaselan, H.A.J.; Ismail, W.I.W. Kinematics Analysis for Five DOF Fresh Fruit Bunch Harvester. Int. J. Agric. Biol. Eng. 2010, 3, $1-7$.

12. Chaminade, C.; Edquist, C. From Theory to Practice: The Use of the Systems of Innovation Approach in innovation Policy. In Innovation, Science and Institutional Change: A Research Handbook; Hage, J., Meeus, M., Eds.; Oxford University Press: Oxford, UK, 2006; pp. 141-162.

13. Woolthuis, R.K.; Lankhuizen, M.; Gilsing, V.A. System failure framework for innovation policy design. Technovation 2005, 25, 609-619. [CrossRef]

14. D'Este, P.; Iammarino, S.; Savona, M.; von Tunzelmann, N. What Hampers Innovation? Evidence from the UK CIS4. Sci. Technol. Res. 2008, 168, 477-500.

15. Dennis, A.; Romanus, N. Adoption of recommended palm oil processing technology in Isoko North Local Government Area, Delta State, Nigeria. Asian J. Agric. Ext. Econ. Sociol. 2018, 24, 1-8. [CrossRef]

16. Nur, S.; Baba, M.D.; Norani, N. Barriers of adopting harvesting technology in Malaysian oil palm industry. Aust. J. Basic Appl. Sci. 2014, 8, 198-200.

17. Ajayi, M.T.; Solomon, O. Influence of Extension Contact and Farmers' Socio-economic Characteristics on Adoption of Oil Palm Technologies in Aniocha North Local Government, Delta State, Nigeria. J. Agric. Sci. Technol. 2010, 12, 35-46.

18. Tornatsky, L.; Fleischer, M. The Process of Technology Innovation; Lexington Books: Lexington, MA, USA, 1990.

19. Rogers, E.M. Diffusion of Innovations; A Division of Simon \& Schuster Inc.: New York, NY, USA, 2003.

20. Nelson, R.R. Economic Development from the Perspective of Evolutionary Economic Theory. Oxf. Dev. Stud. 2008, 36, 9-21. [CrossRef]

21. Lim, C.L. The use of spherical sterilizer for sterilization of fresh fruit bunches. PIPOC Int. Palm Oil Cong. 2007, 89, 29-38.

22. Loh, T. The way forward in the palm oil milling process with the advent of TILTING STERILIZER. Int. Palm Oil Cong. 2009, 94, $29-42$.

23. Schuchardt, F.; Wulfert, K.; Darnoko, D.; Herawan, T. Effect of new palm oil mill processes on the EFB and POME Utilization. J. Oil Palm Res. 2008, D1743, 115-126.

24. Chew, C.L.; Low, L.E.; Chia, W.Y.; Chew, K.W.; Liew, Z.K.; Chan, E.S.; Chan, Y.J.; Kong, P.S.; Show, P.L. Prospects of palm fruit extraction technology: Palm oil recovery processes and quality enhancement. Food Rev. Int. 2021, 17, 1-28. [CrossRef]

25. Hashim, K.; Tahiruddin, S.; Jaril Asis, A. Palm and Palm Kernel Oil Production and Processing in Malaysia and Indonesia. In Palm oil Production, Processing, Characterization, and Uses; Oi-Ming, L., Ching-Ping, T., Casimir, C.A., Eds.; AOCS Press: Urbana, IL, USA, 2012; pp. 232-250.

26. Bello, M.M.; Abdul Raman, A.A. Trend and Current Practices of Palm Oil Mill Effluent Polishing: Application of Advanced Oxidation Processes and Their Future Perspectives. J. Environ. Manag. 2017, 198, 170-182. [CrossRef]

27. Stringer, L.C.; Fraser, E.D.G.; Harris, D.; Lyon, C.; Pereira, L.; Ward, C.F.M.; Simelton, E. Adaptation and development pathways for different types of farmers. Environ. Sci. Policy 2020, 104, 174-189. [CrossRef]

28. Borowski, P.F. Adaptation strategy on regulated markets of power companies in Poland. Energy Environ. 2019, 30, 3-26. [CrossRef]

29. Geels, F.W.; Johnson, V. Towards a modular and temporal understanding of system diffusion: Adoption models and sociotechnical theories applied to Austrian biomass district-heating (1979-2013). Energy Res. Soc. Sci. 2018, 38, 138-153. [CrossRef]

30. Agwu, A.E. Adoption of Improved Oil Palm Production and Processing Technologies in Arochukwu local government area of Abia State, Nigeria. Agro-Sci. 2006, 5, 26-35. [CrossRef]

31. Ugwu, D.S. Problems and prospects of commercial small and medium scale cocoa and oil palm production in Cross River State, Nigeria. Res. J. Appl. Sci. 2009, 5, 827-832.

32. Biodiin, M.B.; Akinlabi, E.T.; Okokpujie, I.P.; Fayomi, O.S.I. An Overview of Palm Oil Production Processing in Nigeria: A Case Study of Ilashe, Nigeria. IOP Conf. Ser. Mater. Sci. Eng. 2021, 1107, 012134. [CrossRef]

33. Rasiah, R. Developmental States: Land Schemes, Parastatals and Poverty Alleviation in Malaysia; University Kebangsaan Malaysia: Bangi, Malaysia, 2018.

34. Ngah, A.H.; Zainuddin, Y.; Ramayah, T. Applying the TOE framework in the Halal warehouse adoption study. J. Islam. Account. Bus. Res. 2017, 8, 161-181. [CrossRef]

35. Lin, C.Y.; Alam, S.S.; Ho, Y.H.; Al-Shaikh, M.E.; Sultan, P. Adoption of Green Supply Chain Management among SMEs in Malaysia. Sustainability 2020, 12, 6454. [CrossRef] 
36. Malik, S.; Chadhar, M.; Vatanasakdakul, S.; Chetty, M. Factors Affecting the Organizational Adoption of Blockchain Technology: Extending the Technology-Organization-Environment (TOE) Framework in the Australian Context. Sustainability 2021, 13, 9404. [CrossRef]

37. Awa, H.O.; Ukoha, O.; Emecheta, B.C. Using T-O-E theoretical framework to study the adoption of ERP solution. Cogent. Bus. Manag. 2016, 3, 1196571. [CrossRef]

38. Ochola, P. An empirical study of determinants of e-commerce adoption amongst micro, small and medium enterprises (MSMEs) in Kenya. Int. J. Econ. Commer. Manag. 2015, 3, 223-240.

39. Mata, F.J.; Fuerst, W.L.; Barney, J.B. Information Technology and Sustained Competitive Advantage: A Resource-Based Analysis. MIS Q. 1995, 19, 487-505. [CrossRef]

40. Gunasekera, D.; Valenzuela, E. Adoption of blockchain technology in the australian grains trade: An assessment of potential economic effects. Econ. Pap. 2020, 39, 152-161. [CrossRef]

41. Yadav, V.S.; Singh, A.R.; Raut, R.D.; Govindarajan, U.H. Blockchain technology adoption barriers in the Indian agricultural supply chain: An integrated approach. Resour. Conserv. Recycl. 2020, 161, 104877. [CrossRef]

42. Ngongo, B.P.; Ochola, P.; Ndegwa, J.; Katuse, P. The technological, organizational and environmental determinants of adoption of mobile health applications (m-health) by hospitals in Kenya. PLoS ONE 2019, 14, e0225167. [CrossRef]

43. Ramdani, B.; Kawalek, P.; Lorenzo, O. Knowledge management and enterprise systems adoption by SMEs: Predicting SMEs' adoption of enterprise systems. J. Enterp. Inf. Manag. 2009, 22, 10-24. [CrossRef]

44. Parthasarathy, S.; Mohammed, R.R.; Fong, C.M.; Gomes, R.L.; Manickam, S.A. Novel hybrid approach of activated carbon and ultrasound cavitation for the intensification of palm oil mill effluent (POME) polishing. J. Clean. Prod. 2016, 112, 1218-1226. [CrossRef]

45. Said, M.; Ahmad, A.; Mohammad, A.W.; Nor, M.T.M.; Sheikh Abdullah, S.R. Blocking mechanism of PES membrane during ultrafiltration of POME. J. Ind. Eng. Chem. 2015, 21, 182-188. [CrossRef]

46. Sivasothy, K.; Basiron, Y.; Anhar, S.; Ramli, T.; Tan, H.; Mohammad, S. Continuous Sterilization: The new Paradigm for modernizing palm oil milling. J. Oil Palm Res. 2006, 144-152.

47. Wahid, M.B.; Simeh, M.A. Issue related to production cost of palm oil in Malaysia. Oil Palm Indus. Econ. J. 2009, 9, 1-12.

48. Clarke, L.; Bishop, C. Farm power-present and future availability in developing countries. Int. J. Agric. Eng. 2002, 4, 1-19.

49. Nordin, A.Z.A.; Rahman, Z.A.; Hashim, Z.; Hadi, N.A.; Ismail, A.; Balu, N. Economic Assessment of Zero Waste Technology for Palm Oil Mills in Malaysia. In Proceedings of the Palm Oil Economic and Review and Outlook (R\&O) Seminar 2019, Malaysian Palm Oil Board, Selangor, Malaysia, 17 January 2019.

50. Baluch, N.; Sobry Abdullah, C.; Mohtar, S. Evaluating Effective Spare-parts Inventory Management for Equipment Reliability in Manufacturing Industries. Eur. J. Manag. Bus. Manag. 2013, 5, 69-75.

51. Barrantes, J.O. System of Innovation and Cleaner Technologies in the Palm Oil Sector Costa Rica. In DRUID's Nelson and Winter Conference. 2001. Available online: http//www.business.auc.dk/druid/conferences/nw/paper1/barrantes.pdf (accessed on 24 June 2021).

52. Ravi Menon, N. Possible changes in milling technology. Palm Oil Eng. Bull. 2017, 123, 11-17.

53. Wymer, S.A.; Regan, E.A. Factors influencing e-commerce adoption and use by small and medium businesses. Electron. Mark. 2005, 15, 438-453. [CrossRef]

54. Burns, T.; Stalker, G.M. The Management of Innovation; Tavistock Publication: London, UK, 1961; pp. 120-122.

55. Daft, R.L.; Becker, S.W. Innovation in Organizations: Innovation Adoption in School Organizations; Elsevier: Amsterdam, The Netherlands, 1978; 229p.

56. Ukobitz, D.V. Organizational adoption of 3D printing technology: A semisystematic literature review. J. Manuf. Technol. Manag. 2020, 32, 1-27. [CrossRef]

57. Baker, J. The Technology-Organization-Environment Framework. Inf. Syst. Theory 2012, 1, 231-245.

58. Zaltman, G.; Duncan, R.; Holbeck, J. Innovations and Organizations; Wiley: New York, NY, USA, 1973.

59. Brynjolfsson, E.; Hitt, L. Paradox Lost? Firm-Level Evidence on the Returns to Systems Spending. Manag. Sci. 1996, 42, 541-558. [CrossRef]

60. Munyua, A.W. Global Information Society Watch Focus on ICTs and Environmental Sustainability; APC: Johannesburg, East Africa; HIVOS: The Hague, The Netherlands, 2010; pp. 161-163.

61. Cetindamar, D.; Phaal, R.; Probert, D. Understanding technology management as a dynamic capability: A framework for technology management activities. Technovation 2009, 29, 237-246. [CrossRef]

62. Knight, R. Convincing Skeptical Employees to Adopt New Technology. Harv. Bus. Rev. 2015, 2-7. Available online: https:/ /hbr.org/2015/03/convincing-skeptical-employees-to-adopt-new-technology (accessed on 23 May 2018).

63. Tushman, M.; Nadler, D. Organizing for Innovation. Calif. Manag. Rev. 1986, 28, 74-94. [CrossRef]

64. Griliches, Z. Patent Statistics as Economic Indicators: A Survey. J. Econ. Lit. 1990, 28, 1661-1707.

65. Herold, D.M.; Jayaraman, N.; Narayanaswamy, C.R. What is the relationship between organizational slack and innovation? J. Manag. Issues 2006, 18, 372-392.

66. Hameed, M.A.; Counsell, S.; Swift, S. A conceptual model for the process of IT innovation adoption in organizations. J. Eng. Technol. Manag. 2012, 29, 358-390. [CrossRef] 
67. Hutchinson, K.; Donnell, L.V.; Gilmore, A.; Reid, A. Loyalty card adoption in SME retailers: The impact upon marketing management. Eur. J. Mark. 2015, 49, 467-490. [CrossRef]

68. Markus, M.L.; Loebbecke, C. Commoditized digital processes and business community platforms: New opportunities and challenges for digital business strategies. MIS Q. 2013, 37, 649-654.

69. Alali, F.A.; Yeh, C.L. Cloud computing: Overview and risk analysis. J. Inf. Syst. 2012, 26, 13-33. [CrossRef]

70. Govindan, K.; Kaliyan, M.; Kannan, D.; Haq, A. Barriers analysis for green supply chain management implementation in Indian industries using analytic hierarchy process. Int. J. Prod. Econ. 2014, 47, 555-568. [CrossRef]

71. Chandra, S.; Kumar, K.N. Exploring factors influencing organizational adoption of augmented reality in e-commerce: Empirical analysis using technology-organization-environment model. J. Electron. Commer. Res. 2018, 19, 237-265.

72. Wongsim, M. The Importance of Influences Factors for Chooses and Use of Software and Hardware to Support Operations in Accounting Information Systems Adoption. J. Southeast Asian Res. 2013, 2013, 503638.

73. Kuan, K.K.; Chau, P.Y. A perception-based model for EDI adoption in small businesses using a Technology-OrganizationEnvironment framework. Inf. Manag. 2001, 38, 507-521. [CrossRef]

74. Ghobakhloo, M.; Sabouri, M.S.; Hong, T.S.; Zulkifli, N. Information technology adoption in small and medium- sized enterprises; An Appraisal of Two Decades Literature. Interdiscip. J. Res. Bus. 2011, 1, 53-80.

75. Thong, J.; Yap, C. CEO characteristics, organisational characteristics and information technology adoption in small business Omega Int. J. Manag. Sci. 1995, 23, 429-442. [CrossRef]

76. Pan, M.-J.; Jang, W.-Y. Determinants of the adoption of enterprise resource planning within the technology-organizationenvironment framework: Taiwan's communications industry. J. Comput. Inf. Syst. 2008, 48, 94-102.

77. Kim, D.Y.; Jang, S.; Morrison, A.M. Factors Affecting Organizational Information Technology Acceptance: A Comparison of Convention and Visitor Bureaus and Meeting Planners in the United States. J. Conv. Event Tour. 2011, 12, 1-24. [CrossRef]

78. Qureshi, M.I.; Rasiah, R.A.; Al-Ghazali, B.M.; Haider, M.; Jambari, H. Modeling work practices under socio-technical systems for sustainable manufacturing performance. Sustainability 2019, 11, 4294. [CrossRef]

79. Grover, V. From business reengineering to business process change management: A longitudinal study of trends and practices. IEEE Trans. Eng. Manag. 1999, 46, 36-46. [CrossRef]

80. Lee, J.C.; Shiue, Y.C.; Chen, C.Y. Examining the impacts of organizational culture and top management support of knowledge sharing on the success of software process improvement. Comput. Hum. Behav. 2016, 54, 462-474. [CrossRef]

81. Sila, I. Factors Affecting the Adoption of B2B E-commerce Technologies. J. Electron. Commer. Res. 2013, 13, 199-236. [CrossRef]

82. Wüstenhagen, R.M.; Wolsink, R.M.; Bürer, M.J. Social Acceptance of Renewable Energy Innovation: An Introduction to the Concept. Energy Policy 2007, 35, 2683-2691. [CrossRef]

83. Lin, H.F.; Lee, G.G. Impact of Organizational Learning and Knowledge Management Factors on E-Business Adoption. Manag. Decis. 2005, 43, 171-188. [CrossRef]

84. Thong, J.Y.L. An integrated model of information systems adoption in small businesses. Manag. Inf. Syst. 1999, 15, 187-214. [CrossRef]

85. Madaki, Y.S.; Seng, L. Pollution Control: How Feasible is Zero Discharge Concepts in Malaysia Palm Oil Mills. Am. J. Eng. Res. 2013, 2, 239-252.

86. Abdullah, M.; Zailani, S.; Iranmanesh, M.; Jayaraman, K. Barriers to green innovation initiatives among manufacturers: The Malaysian case. Rev. Manag. Sci. 2015, 10, 683-709. [CrossRef]

87. Baluch, N. Maintenance Management Performance of Malaysian Palm Oil Mills. Ph.D. Thesis, University Utara Malaysia, Kedah, Malaysia, 2012.

88. Bennett, J.; Pokingtorne, M. Technology Transfer for SMEs. J. Manuf. Eng. 1998, 6, 234-245. [CrossRef]

89. Schumpeter, J.A. The Theory of Economic Development; Harvard University Press: Cambridge, MA, USA, 1934.

90. David, P.A. Technical Innovation and Economic Growth; Cambridge University Press: Cambridge, MA, USA, 1975.

91. Davies, S. The Diffusion of Process Technologies; Cambridge University Press: Cambridge, MA, USA, 1979.

92. Nelson, R.; Winter, S. An Evolutionary Theory of Economic Change; Harvard Business Press: Cambridge, MA, USA, 1982.

93. Lall, S. India's Manufactured Exports: Comparative Structure and Prospects. World Dev. 1999, 27, 1769-1786. [CrossRef]

94. Geroski, P.A. Models of Technology Diffusion. Res. Policy 2000, 29, 603-625. [CrossRef]

95. Hall, B.H.; Khan, B. Adoption of New Technology. In New Economy Handbook; Jones, D.C., Ed.; Elsevier Science: Amsterdam, The Netherlands, 2003; pp. 230-251.

96. Zhu, K.; Kraemer, K. Post-adoption variations in usage and value of E-business by organizations: Cross-country evidence from the retail industry. Inf. Syst. Res. 2005, 16, 61-84. [CrossRef]

97. Piore, M.J.; Sabel, C.F. The Second Industrial Divide: Possibilities for Prosperity; Basic Books: New York, NY, USA, 1984.

98. Ahmad, N.A.; Drus, S.M.; Kasim, H. Factors That Influence the Adoption of Enterprise Architecture by Public Sector Organizations: An Empirical Study. IEEE Access. 2020, 8, 98847-98873. [CrossRef]

99. Gallego, J.M.; Gutierrez, L.H.; Lee, S.H.A. A firm-level analysis of ICT adoption in an emerging economy: Evidence from the Colombian manufacturing industries. Ind. Corp. Chang. 2014, 24, 191-221. [CrossRef]

100. Gallego, J.M.; Gutiérrez, L.H.; Taborda, R. Innovation and productivity in the Colombian service and manufacturing industries. Emerg. Mark. Finance Trade 2015, 51, 612-634. [CrossRef] 
101. Jeyaraj, A.; Rottman, J.; Lacity, M. A review of the predictors, linkages, and biases in IT innovation adoption research. J. Inf. Technol. 2006, 21, 1-23. [CrossRef]

102. Maqueira-Marin, J.M.; Bruque-Cámara, S.; Minguela-Rata, B. Environment Determinants in Business Adoption of Cloud Computing. Ind. Manag. Data Syst. 2017, 117, 228-246. [CrossRef]

103. Oh, K.Y.; Cruickshank, D.; Anderson, A.R. The Adoption of E-trade Innovations by Korean Small and Medium Sized Firms. Technovation 2009, 29, 110-121. [CrossRef]

104. Zhu, K.; Kraemer, K.; Xu, S. Electronic business adoption by European firms: A cross-country assessment of the facilitators and inhibitors. Eur. J. Inf. Syst. 2003, 12, 251-268. [CrossRef]

105. Zailani, S.; Iranmanesh, M.; Sean Hyun, S.; Ali, M.H. Barriers of Biodiesel Adoption by Transportation Companies: A Case of Malaysian Transportation Industry. Sustainability 2019, 11, 931. [CrossRef]

106. Rodríguez-Ardura, I.; Meseguer-Artola, A. Toward a Longitudinal Model of e-Commerce: Environmental, Technological, and Organizational Drivers of B2C Adoption. Inf. Soc. 2010, 26, 209-227. [CrossRef]

107. Bayo-Moriones, A.; Lera-Lopez, F. A Firm-Level Analysis of Determinants of ICT Adoption in Spain. Technovation 2007, 27, 352-366. [CrossRef]

108. Hambali, M.S. Palm oil demand up in Turkey: Pricing a key factor. Glob. Oils Fats Bus. Mag. 2015, 12, 18-20.

109. Rasiah, R.; Sharin, A. The Development of Palm Oil and Related Products in Malaysia and Indonesia. Unpublished Paper. 2006. Available online: https://www.researchgate.net/publication/237474157_Development_of_Palm_Oil_and_Related_Products_ in_Malaysia_and_Indonesia (accessed on 14 December 2021).

110. Taha, M.R.; Ibrahim, A.H. COD removal from anaerobically treated palm oil mill effluent (AT-POME) via aerated heterogeneous Fenton process: Optimization study. J. Water Process Eng. 2014, 1, 8-16. [CrossRef]

111. Abas, R.; Kamarudin, M.F.; Nordin, A.A.B.; Simeh, M.A. A study on the Malaysian oil palm biomass sector-supply and perception of palm oil millers. Oil Palm Indus. Econ. J. 2011, 11, 28-41.

112. Wu, H.-L.; Lin, B.-W.; Chen, C.-J. Examining governance-innovation relationship in the high-tech industries: Monitoring, incentive and a fit with strategic posture. Int. J. Technol. Manag. 2007, 39, 86-104. [CrossRef]

113. Egwu, E.W. Factors affecting farmer's adoption of agricultural innovation in Delta State. J. Agric. Ext. Rural Dev. 2015, 3, 177-182.

114. Onwude, D.; Abdulstter, R.; Gomes, C.; Hashim, N. Mechanisation of large-scale agricultural fields in developing countries-A review. J. Sci. Food Agric. 2016, 96, 3969-3976. [CrossRef]

115. Borowski, P.F. Significance and directions of energy development in African countries. Energies 2021, 14, 4479. [CrossRef]

116. Creswell, J.W.; Hanson, W.E.; Clark Plano, V.L.; Morales, A. Qualitative Research Designs. Couns. Psychol. 2007, 35, $236-264$. [CrossRef]

117. Keller, G. Managerial Statistics, 8th ed.; South-Western Cengage Learning: Mason, OH, USA, 2008.

118. Berenson, M.; Leveine, D.; Szabat, K.A. Basic Business Statistics: Concepts and Applications, 13th ed.; Pearson Higher Education: Melbourne, Australia, 2014

119. Lahaut, V.M.; Jansen, H.A.; van de Mheen, D.; Garretsen, H.F.; Verdurmen, J.E.; Van Dijk, A. Estimating non-response bias in a survey on alcohol consumption: Comparison of response waves. Alcohol Alcohol. 2003, 38, 128-134. [CrossRef]

120. Armstrong, J.S.; Overton, T.S. Estimating nonresponse bias in mail surveys. J. Market. Res. 1977, 14, 396-402. [CrossRef]

121. De Winter, J.F.C.; Dodou, D. Five-point likert items: T test versus Mann-Whitney-Wilcoxon (Addendum added October 2012). Pract. Assess. Res. Eval. 2010, 15, 11.

122. Adéoti, O.; Tamò, R.; Coulibaly, M. Facteurs affectant l'adoption des nouvelles technologies du niébé Vigna unguiculata en Afrique de l'Ouest'. Bull. Rech. Agron. Bénin. 2003, 36, 19-32.

123. Bagozzi, R.P.; Yi, Y. On the Evaluation of Structural Equation Models. Acad. Mark. Sci. Rev. 1988, 16, 74-94. [CrossRef]

124. Hair, J.F.; Black, W.C.; Babin, B.J.; Anderson, R.E. Multivariate Data Analysis: A Global Perspective, 7th ed.; Pearson Prentice Hall: Upper Saddle River, NJ, USA, 2010.

125. Hair, J.F.; Anderson, R.E.; Tatham, R.L.; Black, W.C. Multivariate Data Analysis, 5th ed.; Prentice Hall: Upper Saddle River, NJ USA, 1998.

126. Moore, G.C.; Benbasat, I. Development of an instrument to measure the perceptions of adopting an information technology innovation. Inf. Syst. Res. 1991, 2, 192-222. [CrossRef]

127. Sulo, T.; Koech, P.; Chumo, C.; Chepngeno, W. Socio-economic Factors Affecting the Adoption of Improved Agricultural Technologies among Women in Marakwet County Kenya. J. Emerg. Trends Econ. Manag. Sci. 2012, 3, 312-317.

128. Ghobakhloo, M.; Arias-Aranda, D.; Benitez-Amado, J. Adoption of e-commerce applications in SMEs. Ind. Manag. Data Syst. 2011, 111, 1238-1269. [CrossRef]

129. Jeon, B.N.; Han, K.S.; Lee, M.J. Determining Factors for the Adoption of e-Business: The Case of SMEs in Korea. Appl. Econ. 2006, 38, 1905-1916. [CrossRef]

130. Zhu, K.; Dong, S.; Xu, S.X.; Hally, M. Innovation diffusion in global contexts: Determinants of post-adoption digital transformation of European companies. Eur. J. Inf. Syst. 2006, 15, 601-616. [CrossRef]

131. Fornell, C.; Larcker, D. Evaluating structural equation models with unobservable variables and measurement error. J. Mark. Res. 1981, 18, 39-50. [CrossRef]

132. Kleinbaum, D.; Kupper, L.; Muller, K. Applied Regression Analysis and Other Multivariate Methods; PWS: Boston, MA, USA, 1988.

133. Bowerman, B.; Connell, R. Business Statistics in Practice, 2nd ed.; McGraw-Hill/Irwin: Boston, MA, USA, 2001. 
134. Henriksen, H. Motivators for IOS adoption in Denmark. J. Electron. Commer. Organ. 2006, 4, 25-39. [CrossRef]

135. Harun, M.Y.; Yunus, M.A.C.; Morad, N.A.; Ismail, M.H.S. An industry survey of the screw press system in palm oil mills: Operational data and malfunction issues. Eng. Fail. Anal. 2015, 54, 146-149. [CrossRef]

136. Ogada, M.J.; Mwabu, G.; Muchai, D. Farm technology adoption in Kenya: A simultaneous estimation of inorganic fertilizer and improved maize variety adoption decisions. Agric. Food Econ. 2014, 2, 1-18. [CrossRef]

137. Bhattacharya, M.; Wamba, S.F.A. Conceptual Framework of RFID Adoption in Retail Using TOE Framework. Int. J. Technol. Manag. 2015, 6, 1-32. [CrossRef]

138. Ho"lzl, W.; Janger, J. Distance to the frontier and the perception of innovation barriers across European countries. Res. Policy 2014, 43, 707-725. [CrossRef]

139. Baluch, N.H.; Abdullah, C.S.; Mohtar, S. Maintenance management performance-An overview towards evaluating Malaysian palm oil mill. Asian J. Technol. Manag. 2010, 3, 1-5.

140. Silva, M.J.; Leitao, J.; Raposo, M. Barriers to innovation faced by manufacturing firms in Portugal: How to overcome it for fostering business excellence? Int. J. Bus. Excell. 2008, 1, 92-105. [CrossRef]

141. Perron, M. Barriers to Environmental Performance Improvements in Canadian SMEs. Ph.D. Thesis, Dalhousie University, Halifax, NS, Canada, 2005.

142. Canepa, A.; Stoneman, P. Financing constraints in the inter-firm diffusion of new process technologies. J. Technol. Transf. 2005, 30, 159-169. [CrossRef]

143. Schumpeter, J. Capitalism, Socialism and Democracy; Allen \& Unwin: London, UK, 1943.

144. Johari, A.; Nyakuma, B.B.; Nor, S.H.M.; Mat, R.; Hashim, H.; Ahmad, A.; Zakaria, Z.Y.; Abdullah, T.A.T. The challenges and prospects of palm oil based biodiesel in Malaysia. Energy 2015, 81, 255-261. [CrossRef]

145. Runhaar, H.; Tigchelaar, C.; Vermeulen, W.J. Environmental leaders: Making a difference. A typology of environmental leaders and recommendations for a differentiated policy approach. Bus. Strateg. Environ. 2008, 17, 160-178. [CrossRef] 